\title{
Geological setting and structural styles of Volcanic Massive Sulfide deposits in the northern Apennines (Italy): evidence for seafloor and sub-seafloor hydrothermal activity in unconventional ophiolites of the Mesozoic Tethys
}

\author{
Giorgio Garuti ${ }^{1,2, *}$, Omar Bartoli ${ }^{2}$, Maurizio Scacchetti ${ }^{2}$, Federica Zaccarini ${ }^{2,3}$ \\ ${ }^{1}$ Dipartimento di Scienze della Terra, Università di Modena e Reggio Emilia, \\ Via S. Eufemia 19, 41100 Modena, Italy. \\ ${ }^{2}$ Società Reggiana di Scienze Naturali, \\ Via Tosti 1, 42100 Reggio Emilia, Italy. \\ ${ }^{3}$ Department Angewandte Geowissenschaften und Geophysik, \\ Montanuniversität Leoben, Peter Tunner Str., 5, 8700 Leoben, Austria. \\ *garutig@unimore.it
}

\begin{abstract}
This paper is an overview of the geological setting and structural styles of Cu-sulfide deposits of the VMS-type, associated with Tethyan ophiolites (the Ligurides) in the northern Apennines (Italy). The Italian deposits represent a rare example of VMS associated with both the mantle-peridotite basement and the overlaying volcanic pile, within a single ophiolite sequence. This peculiar feature is due to the particular geodynamic evolution of the Mesozoic Ligurian ocean that allowed the upper mantle to be exposed on the seafloor for a long period before the outflow of MORB-type lava and the deposition of pelagic sediments (cherts, Palombini shales and Calpionella limestones). Middle to Upper Jurassic uprising of the basaltic magma initially provided the heath source for convective circulation of hydrothermal fluids through the overlaying mantle section, giving rise to sulfide deposition in crosscutting stockworkveins and seafloor-stratiform ore bodies within the serpentinized mantle peridotite and the serpentinite breccia formed by submarine erosion of the upper mantle. The setting and structure of VMS associated with the volcanic pile indicate that hydrothermal activity continued during and after the eruption of pillow basalts at the ocean floor, forming stockwork veins and conformable stratabound ore bodies within the basalt unit. Furthermore, hydrothermal activity formed seafloor-stratiform deposits, at the top of the volcanic pile, covered with a thick horizon of cherts containing exhalative deposits of $\mathrm{Mn}$.
\end{abstract}

Key words: VMS, geological setting, ophiolite, northern Apennine, Italy.

\section{Resumen}

En este trabajo se presenta una visión general del contexto geológico y estilo estructural de los depósitos volcanogénicos de cobre (VMS), asociados a las ofiolitas del Tethys (Las Ligurides), en los Apeninos del Norte Italia. Los depósitos italianos representan un raro ejemplo de VMS ya que se encuentran asociados a los niveles de peridotitas mantélicas basales, y a las rocas volcánicas superiores dentro de una única secuencia ofiolítica. Esta peculiaridad es debida a la evolución geodinámica del océano Ligurian en el Mesozoico, la que ha permitido la exposición del manto en el fondo oceánico por un largo periodo de tiempo antes de la extrusión de lava tipo MORB y la deposición de los sedimentos pelágicos (cherts y pizarras a Palombini y calizas a Calpionella). A lo largo del Jurásico Medio y Superior el emplazamiento de magmas basálticos fue la fuente de calor necesaria para la circulación convectiva de los fluidos hidrotermales a través de los niveles mantélicos. Esta actividad hidrotermal generó la precipitación de sulfuros en forma de stockwork y cuerpos estratiformes dentro de las peridotitas serpentinizadas y las brechas de serpentinitas formadas por la erosión submarina 
del propio manto superior. Por otra parte, el contexto geológico y la estructura de los VMS asociados a las rocas volcánicas sugieren que la actividad hidrotermal ha continuado durante y después la extrusión de las pillow lavas en el fondo oceánico, formando las mineralizaciones en stockwork y depósitos estratoligados dentro de los niveles de basaltos. Finalmente, la actividad hidrotermal también dio lugar a depósitos estratiformes sobre la pila volcánica, así como a depósitos de manganesos asociados a niveles de cherts.

Palabras clave: sulfuros de Cu, VMS, ofiolita, Apeninos del Norte, Italia.

\section{Introduction}

The first discovery of copper in the ophiolites of the northern-Apennine (Italy) is lost in the mist of times. Dating of prehistoric stony and wooden tools recovered from eastern-Liguria ancient mines indicates that copper was a well known commodity about 2000 years B.C. (Galli and Penco, 1996). Written documents bear witness to the cyclic extraction of copper between the Middle Age and the $18^{\text {th }}$ century (Violi Guidetti, 1968; Pipino, 2003). Between 1850 and 1910, systematic exploration led to discovery of more than thirty $\mathrm{Cu}$-sulfide deposits, some of which were intensively mined during the "Autarky" (Moretti, 1937). Economic life of the northern-Apennine deposits came to an end in the sixties and early seventies, when the last mines were closed at Libiola (eastern Liguria), Vigonzano and Ferriere (Emilia Romagna). It is estimated that the northern-Apennine district supplied about 2-3 Mt of ore with an average grade of $2-7 \% \mathrm{Cu}$, between 1850 and 1970 .

Despite their economic importance as the unique copper source in Italy, only sporadic information on mineralogy and geology has been provided for single deposits or limited mining areas (Bertolani 1952, 1959, 1962, 1999; Ferrario, 1973; Brigo and Ferrario, 1974; Ferrario and Garuti, 1980). The deposits of the northern Apennine have been recently re-examined, providing first data on mineralogy and geochemistry of the sulfides (Garuti and Zaccarini, 2005; Zaccarini, 2006; Zaccarini and Garuti, in press), as well as preliminary data on chlorite geothermometry (Zaccarini et al., 2003) and sulfur isotope geochemistry (Garuti et al., 2007). The aim of this paper is to provide a guide to the geological setting and structural characters of the most representative VMS deposits of the northern Apennine, based on newly acquired field observations and the recent geodynamic interpretation of the AlpineApennine ophiolites as an example of unconventional oceanic crust in a marginal basin of the Mesozoic Tethys.

\section{Geological background}

Large fragments of the oceanic crust that floored the Piedmont-Liguria Tethyan basin are mainly exposed in the western-Alps and northern-Apennine orogenic chains (Figure 1). Ophiolites located west of the Sestri-Voltaggio tectonic line (Figure 1a), are characterized by high-P, lowT metamorphism in the eclogite- and blueschist-facies (Dal Piaz, 1974a, 1974b, 1995, 1999; Pognante and Piccardo, 1984; Sandrone et al., 1986; Lombardo et al., 2002). Those presently exposed east of the Sestri-Voltaggio line in eastern Liguria and southern Emilia Romagna (Figure 1b) only display the effects of prehnite-pumpellite-facies oceanic metamorphism and orogenic deformation in a relatively cool regime (Cortesogno et al., 1975). Basalts, gabbros and serpentinites from eastern Liguria have ${ }^{18} \mathrm{O}$ enriched isotopic composition indicating an exchange with fluids below $200^{\circ} \mathrm{C}$, at a near-seafloor position (Barrett and Friedrichsen, 1989). Shales of the sedimentary cover appear to have experienced maximum temperatures and pressures of $160-250^{\circ} \mathrm{C}$ and $2-3 \mathrm{~kb}$, respectively, compatible with burial diagenesis conditions (Leoni et al., 1998).

From the early seventies to present, the PiedmontLiguria ophiolites have received different interpretations concerning their paleo-geographic location (wide-opened ocean vs. narrow marginal basin), geodynamic setting (transform-fault $v s$. axial-rift), and rifting mechanism (symmetric vs. asymmetric extension in a low $v s$. fast spreading center). Evolution of these concepts is documented in a wide literature that has brought forth the unusual character of the Piedmont-Liguria ophiolites compared with Tethyan ophiolites in eastern Mediterranean regions.

\subsection{Stratigraphy of the northern Apennine ophiolites}

Stratigraphic successions in the eastern Liguria ophiolites (Figure 2) cannot be reconciled with the ideal reconstruction of the oceanic crust (Barret and Spooner, 1977; Abbate et al., 1980; Barret, 1982; Cortesogno et al., 1987). A true sheeted dike complex or a well-developed cumulus transition zone is absent. Instead, layered gabbros intrude a lherzolitic mantle with sub-continental petrologic signature (Piccardo et al., 2002, and references) and pillow-lavas or pelagic sediments lie directly on the mantle basement. Most stratigraphic sections are characterized by thick horizons of ophicalcite and ophiolitic breccias generated by seafloor erosion of plutonic and volcanic rocks.

These characters distinguish the ophiolites of northern Italy from those in the eastern Mediterranean Tethys which mainly formed in subduction-influenced geodynamic set- 


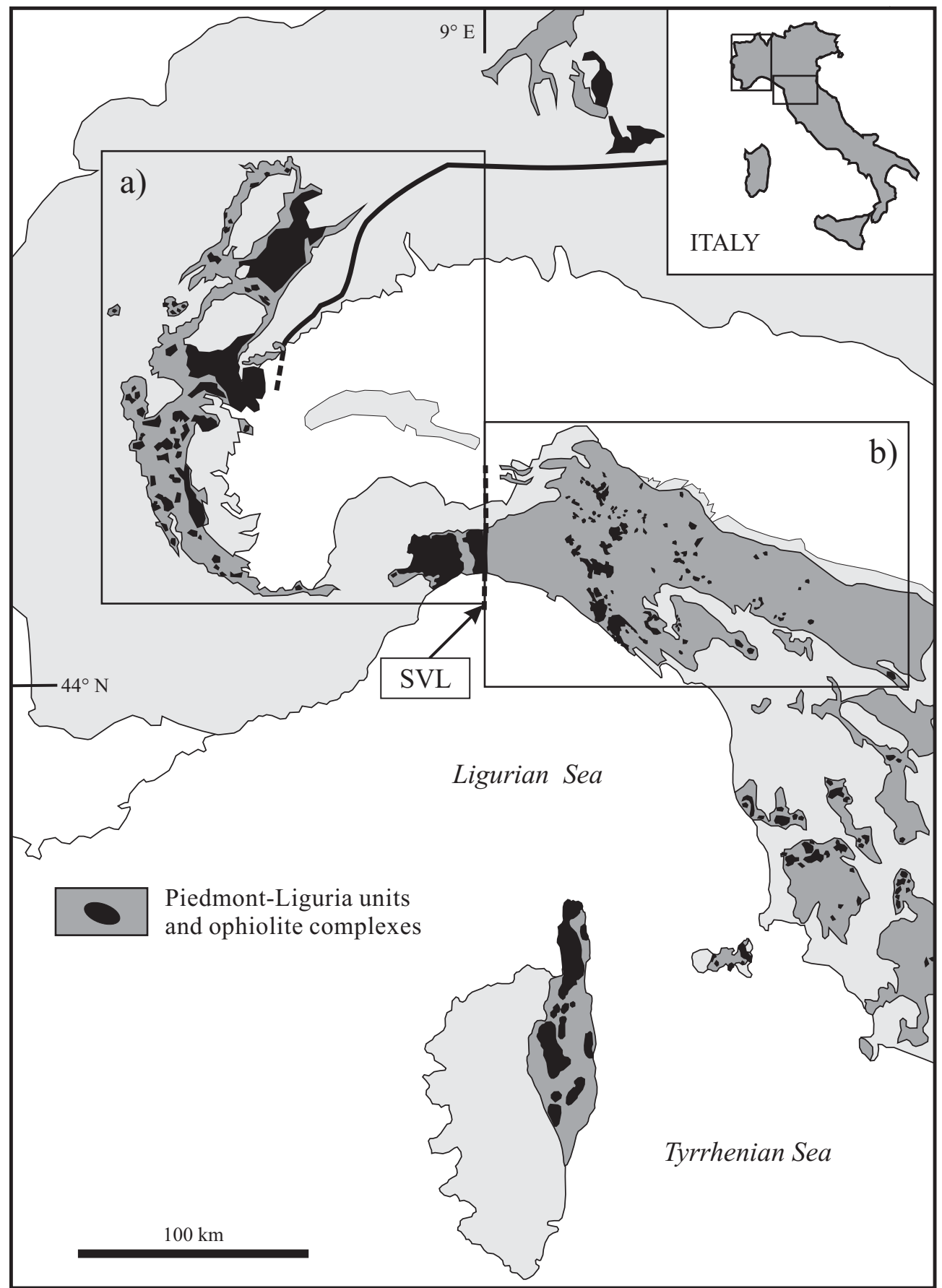

Figure. 1. Simplified structural map of Piedmont-Ligurian units and ophiolite complexes. a) Western Alps ophiolites characterized by high-P, low-T metamorphism in the eclogite- and blueschist-facies. b) Northern Apennine ophiolites with prehnite-pumpellyite-facies oceanic metamorphism and orogenic deformation in a relatively cool regime. SVL = Sestri-Voltaggio tectonic line (modified after Lombardo et al., 2002).

tings (Robertson, 2002). Structural and petrologic features of the Piedmont-Liguria ophiolites are compatible with continental rifting and initial formation of oceanic crust at non-volcanic margins, which characterizes for an extreme thinning of the lithosphere, small volumes of extrusive volcanic rocks, and an upper mantle exhumation onto the seafloor.

\subsection{From rifting to convergence and orogenic exhumation}

The Piedmont-Ligurian oceanic basin (Figure 3) formed by rifting of the Europe and Adria continental plates, in chronological connection with the northern Atlantic ocean opening (Dewey et al., 1973; Biju-Duval et al., 1977; Abbate et al., 1980; Barret, 1982). Passive 
a)

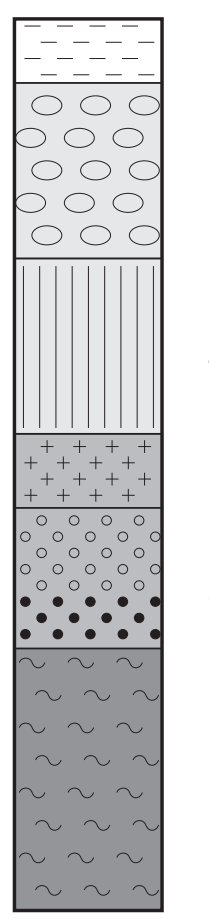

6

5

4

3

2

1 b)

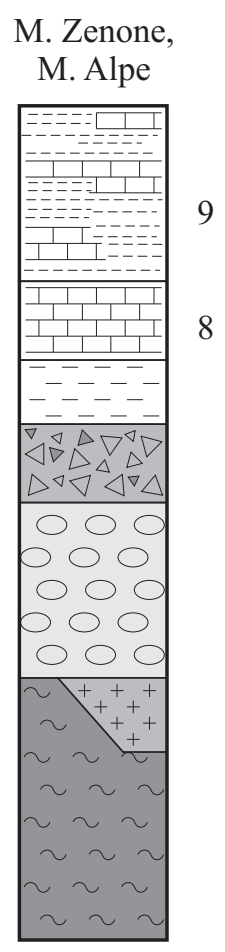

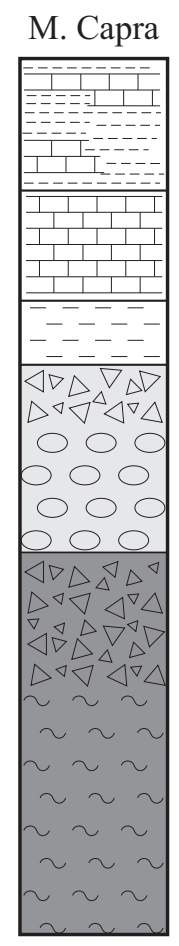

M. Bianco west

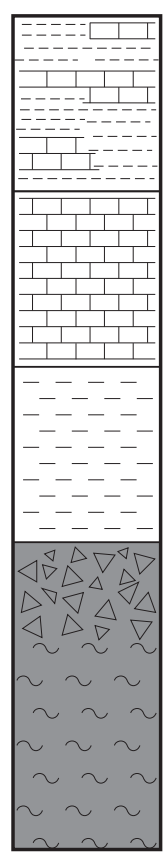

Figure 2. a) Ideal stratigraphy of a subduction-related ophiolite in the eastern Mediterranean basin (Robertson, 2002) compared with: b) typical stratigraphic sections of eastern Liguria ophiolites redrawn after Barret (1982) and Principi et al. (1992). 1) serpentinite, 2) mafic-ultramafic cumulates, 3) gabbro, 4) sheeted dyke complex, 5) pillow lava, 6) chert, 7) ophiolitic breccias, 8) Calpionella limestone, 9) Palombini shale.

extension, possibly driven by an asymmetric detachment fault (Lemoine et al., 1987), initially caused: a thinning of the continental crust, the upwelling of Proterozoic-Permian subcontinental lithospheric mantle, and a progressive intrusion of numerous and relatively small gabbro bodies into the upper mantle (Trias to Middle Jurassic) (Figure 4a). A small ocean basin started to open by pull apart in the continental plates, and the peridotite-gabbro basement was exposed at the spreading seafloor, prior to outflow of MORB-type volcanics and deposition of radiolarian cherts (Upper-Jurassic) (Figure 4b). Massive and pillow basalts formed a laterally discontinuous and relatively thin volcanic-sheet, so that pelagic sediments rested directly on the eroded peridotite-gabbro basement. Prolonged seafloor exposition generated thick ophicalcite horizons at the top of mantle peridotites. Thick deposits of ophiolitic breccia composed of serpentinite, gabbro, basalt and sedimentary fragments accumulated in topographic depressions along valleys and fault scarps of the rugged seafloor, and now form the cover of the peridotite-gabbro basement or pillow-lavas (Cortesogno et al., 1978, 1987; Barret, 1982; Principi et al., 1992). Recession of the seafloor from the axial rifting zone led to progressive burial of the igneousvolcanic basement under pelagic sediments (Figure 4c). The early phases are characterized by deposition of various types of cherts containing Mn-ore deposits (Bonatti et al., 1976; Cabella et al., 1998), passing upward to Lowerand Upper-Cretaceous carbonate-siliciclastic sediments, overlain by various kinds of arenaceous turbidites (UpperCretaceous to Paleocene).

Conversion from a rifting into a convergent movement started in Late Cretaceous causing progressive shrinking and complete closure of the basin (Early Eocene). According to several authors (Piccardo et al., 2002, and references) convergence resulted in intra-oceanic, eastward subduction of the western wing, below the oceanic crust located to the east side of the rifting axes (Figure 4c). Subducted oceanic lithosphere underwent eclogitefacies metamorphism, and was emplaced as west-vergent units in the Piedmont Alps and Liguria Apennine west of the Sestri-Voltaggio line, during the Alpine orogeny. Nonmetamorphic fragments of the oceanic crust located east of the subduction zone were thrust northeastward, over the Adria continental margin, forming a east-vergent tectonic belt, the Liguride nappe (Figure 5a), presently exposed in the northern Apennine chain east of the Sestri-Voltaggio line (Decandia and Elter, 1972; Elter, 1975; Abbate et al., 1980). The nappe is conventionally divided into two different geotectonic units (Figures $4 \mathrm{c}$ and 5a) interpreted as representing fragments of oceanic crust proximal to the east side of the rifting zone (Internal Ligurides) or derived from more distal regions, closer to the ocean-Adria con- 

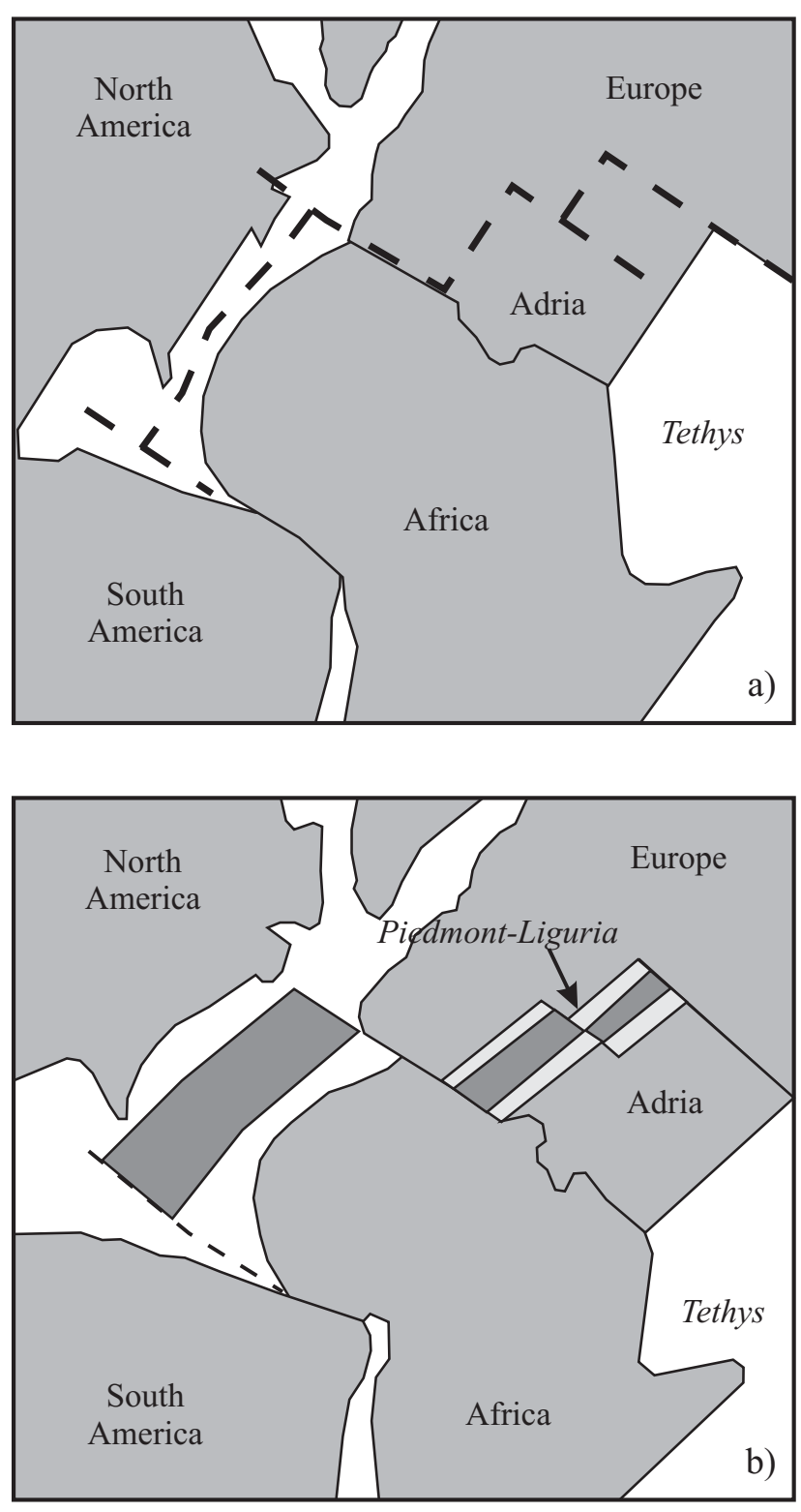

Figure 3. a) Initial break up of Pangea at the end of Triassic, and b) paleogeographic location of the Piedmont-Liguria opening basin with respect to Tethys and north Atlantic ocean during Upper Jurassic and Lower Cretaceous (modified after Piccardo et al., 2002).

tinent transition (External Ligurides). Paleogeographic location within the oceanic basin corresponds to different petrologic characters of the mantle peridotites and basalts, reflecting decreasing degree of depletion from the Internal to the External Ligurides (Venturelli et al., 1981; Capedri and Toscani, 2000; Piccardo et al., 2002). Furthermore, the degree of tectonic deformation and dismembering remarkably increases from the Internal to the External Ligurides.

The Internal Ligurides are presently located in uppermost position within the nappe, being partly overthrust onto the External Ligurides northeastward (Figure 5b). The associated ophiolites form the base of deeply folded, eastward-verging structural units, bounded by southwestward-dipping fault planes, in which primary stratigraphic contacts with the original sedimentary cover are commonly preserved (Decandia and Elter, 1972; Barret, 1982). Upper Jurassic cherts, representing the early oceanic sediments, rest on ophiolitic rocks and pass upward to Calpionella limestone and Palombini shale (Lower Cretaceous). These pelagic sediments are in turn overlain by the Val Lavagna shale and Monte Gottero Flysch (Upper Cretaceous to Paleocene), the latter probably representing turbiditic sedimentation along continental-scarps during post-Cretaceous convergence.

The External Ligurides are overlain by the Internal Ligurides toward the southwest boundary of the Liguride nappe (Figure $5 b$ ) and are unconformably covered by discontinuous slab of Middle Eocene to Upper Miocene sediments (Epiligurian successions) to the northeast (Decandia and Elter, 1972; Elter, 1975; Marroni et al., 2002). The ophiolites occur as dismembered blocks of kilometric to metric size, embedded in a sedimentary mélange formed by polyphase tectonic disruption of the Cretaceous sedimentary cover. The degree of fragmentation increases and the size of the ophiolitic blocks decreases northeastward, where the sedimentary mélange assumes a completely chaotic assemblage with single fragments of calcareous or siliciclastic rocks or packages of turbidite beds floating in clayey-sandy matrix (Pini, 1999). Folding, boudinage, disruption and slumping deformation of non-consolidated sedimentary strata are compatible with syn-thrust gravitational tectonic. Large-scale olistostromes formed by submarine debris avalanches are frequent in the easternmost front of thrusting (Abbate et al., 1970; Pini, 1999). In ophiolitic blocks of kilometer to hundreds meters in size, internal stratigraphic relationships among various ophiolite lithologies (mantle tectonite, ophiolitic breccias, gabbro, pillow basalt) and Upper Jurassic cherts may still be recognizable. However, the igneous rocks and cover sediments generally occur as isolated blocks of less than a few ten of meters within the mélange.

\section{The VMS deposits of the northern Apennine}

Several Cu-sulfide deposits are known in the PiedmontLiguria ophiolite belt (Dal Piaz, 1971; Ferrario, 1977). Those located in the northern Apennine section are particularly relevant because they contain more than $2 / 3$ of the ophiolite-hosted $\mathrm{Cu}$ reserves of Italy, and lack the high-P, low-T metamorphic overprint, providing a unique opportunity for the study of primary ore genesis. Schematic stratigraphy of the northern Apennine sulfide deposits is shown in Figure 6, after Ferrario and Garuti (1980) and Garuti and Zaccarini (2005). Four major structural types can be identified: 1) stratiform ores occurring in the serpentinite breccia, covered by pillow lava; 2) stratiform ores located at the top of the volcanic pile covered with sediments; 3 ) 


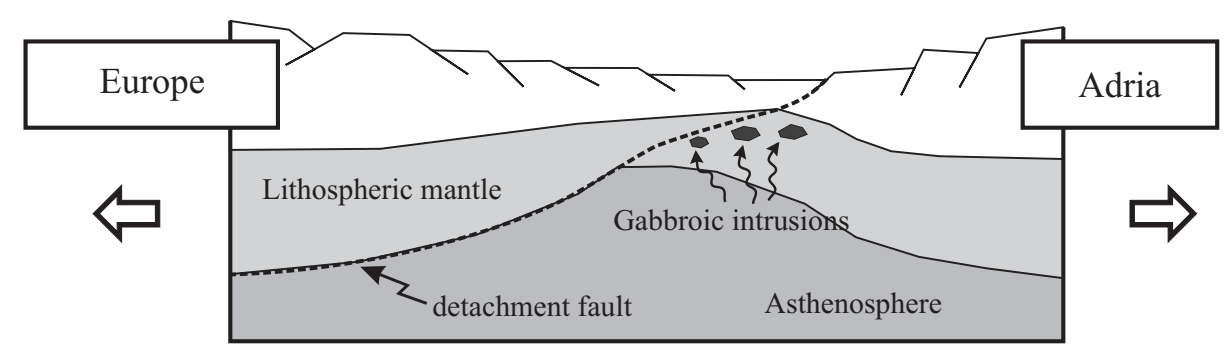

a) Trias to Middle Jurassic

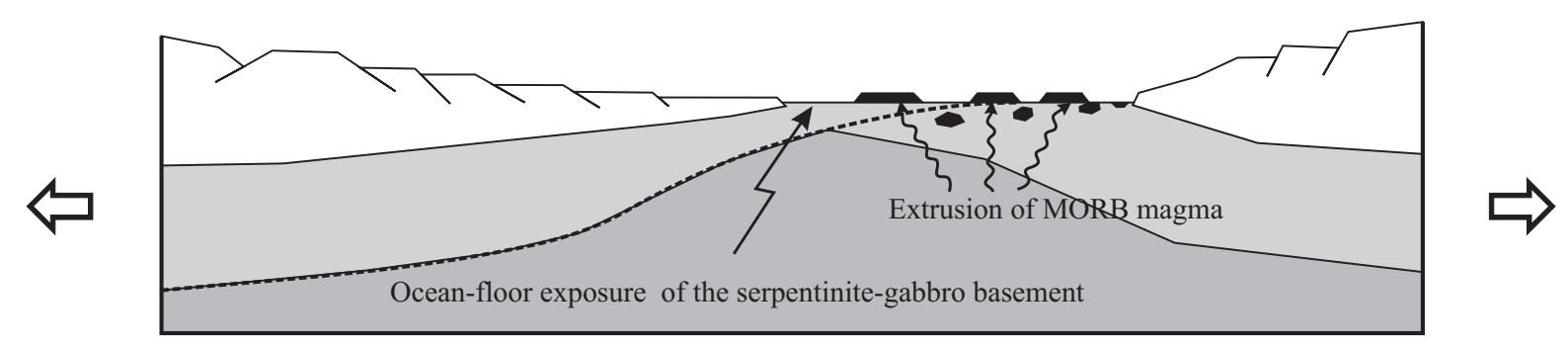

b) Middle-Upper Jurassic

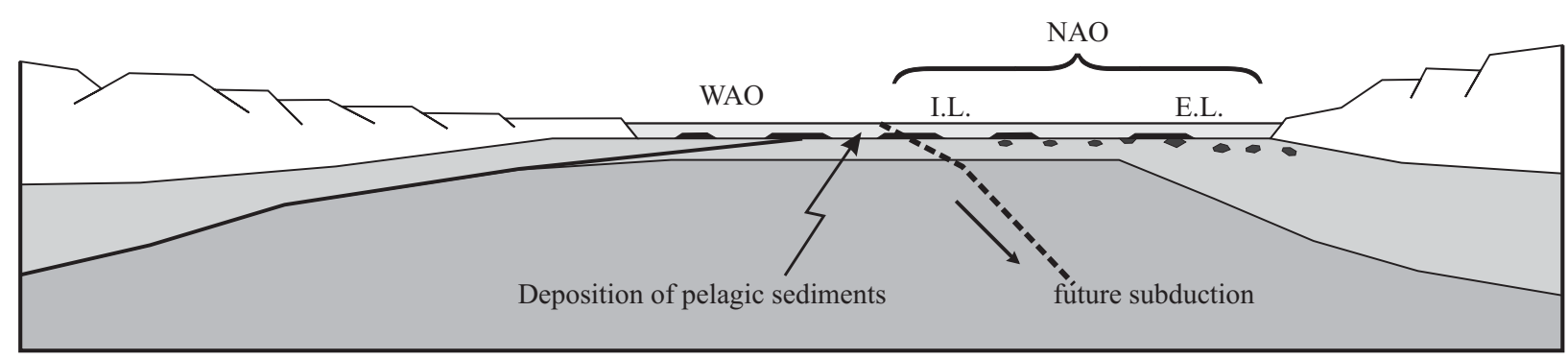

c) Upper Jurassic to Lower Cretaceous

Figure 4. Geotectonic reconstruction of three main stages of opening of the Piedmont-Ligurian ocean from Trias (a) to Middle-Upper Jurassic (b) and Lower Cretaceous (c). The last stage shows location of the future intra-oceanic subduction, and geological setting of the oceanic crusts that will originate the eclogite-metamorphic ophiolites of the westwern Alps (WAO) and the low-grade ocean and orogeny metamorphic ophiolites of the northern Apennine (NAO). Paleo-geographic location of the Internal (I.L.) and External Ligurides (E.L.) is shown.

stratabound deposit located within pillow basalt; 4) sulfide deposits associated with hydrothermal veins cutting across serepentinite (4a), gabbro (4b) and pillow basalt (4c).

Main ore assemblages and representative compositions of the bulk ore are reported in Table 1. Based on paragenetic association and geological setting, the deposits of the northern Apennine are interpreted as Volcanic Massive Sulfides (VMS), i.e.: volcanic-associated massive sulfide deposits formed by hydrothermal precipitation of sulfide minerals at or below the seafloor, in a wide range of geological settings (Barrie and Hannington, 1999). In particular, they pertain to the group of ophiolite-hosted VMS characterized by predominant $\mathrm{Fe}-\mathrm{Cu}-\mathrm{Zn}$ sulfide assemblage and close association with mafic-ultramafic rocks representing the substrate of ancient oceanic basins (Galley and Koski, 1999). Consistent with this assumption, mantle-normalized $\mathrm{Pb}-\mathrm{Ag}-\mathrm{Au}-\mathrm{Zn}-\mathrm{Cu}$ distribution pattern of the northern Apennine deposits broadly parallels the metal-pattern of Cyprus-type VMS, characterized by low $\mathrm{Pb}$ and a moderate Au-anomaly (Zaccarini and Garuti, in press), but differ from back-arc, intraoceanic and intracontinental setting VMS (Figure 7a). The positive Au-anomaly is essentially due to the contribution of the stratiform ores that are enriched in $\mathrm{Au}$, regardless to their association with basaltic or ultramafic rocks (Garuti and Zaccarini, 2005) (Figure 7b).

\section{Sulfide deposits in the Internal Ligurides}

The most relevant VMS deposits of the InternalLigurides described by Ferrario and Garuti (1980) occur in the northernmost of two ophiolite blocks, the Val Graveglia complex, exposed between the eastern-Liguria 


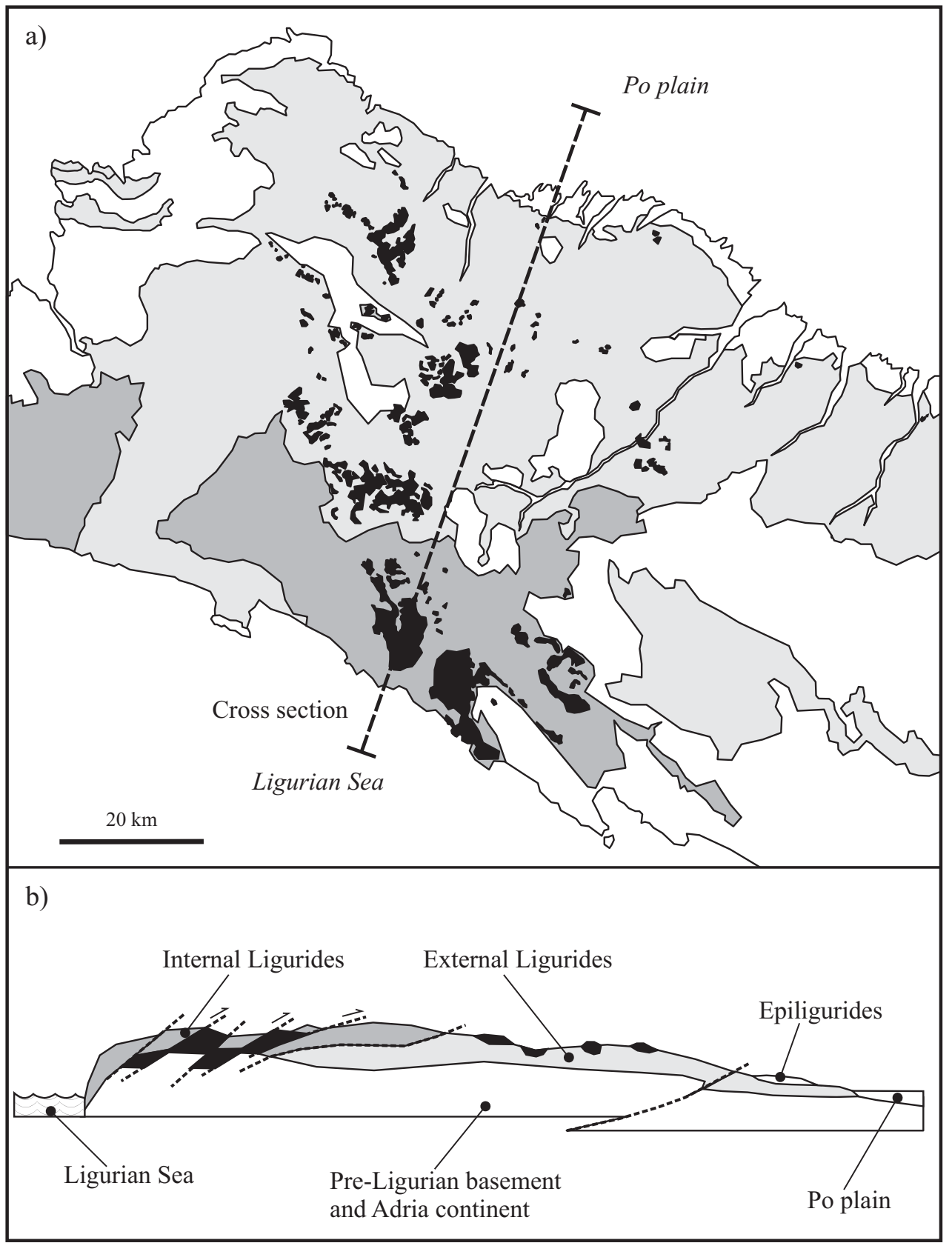

Figure 5. Tectonic sketch map (a) and cross section (b) of the northern Apennine Ligurian terranes. Dark grey: Internal Ligurides, medium grey: External Ligurides, black: ophiolite complexes. Redrawn after Marroni et al. (2002) and Pagani et al. (1972).

coast and the Vara-river valley (Figure 8). The type of ore deposits and their geographic location, identified by GPS coordinates of major mining features (underground adits, open pits, dumps etc.), are summarized in Table 2.

\subsection{The Monte Bardeneto - Monte Bianco mines}

The deposits of Monte Bardeneto and Monte Bianco (Figure 9) are among the best examples of stratiform sulfide ore in serpentinite breccia (type 1). At both locali- ties, a complete stratigraphic sequence from the serpentinite basement to pillow basalt, chert, and Calpionella limestone is exposed. Structural interpretation (Decandia and Elter, 1972) indicates a reverse stratigraphic sequence, the cross section probably representing the lower wing of a deeply eroded, eastward-verging fold, with the axial plane dipping westward, at low angle (see profile in Figure 9). The transition from the serpentinite basement to pillow basalt is marked by several meters of breccia mainly composed of serpentinite blocks, up to more than ten centimeters in size, with minor fragments of sandstone and 
128
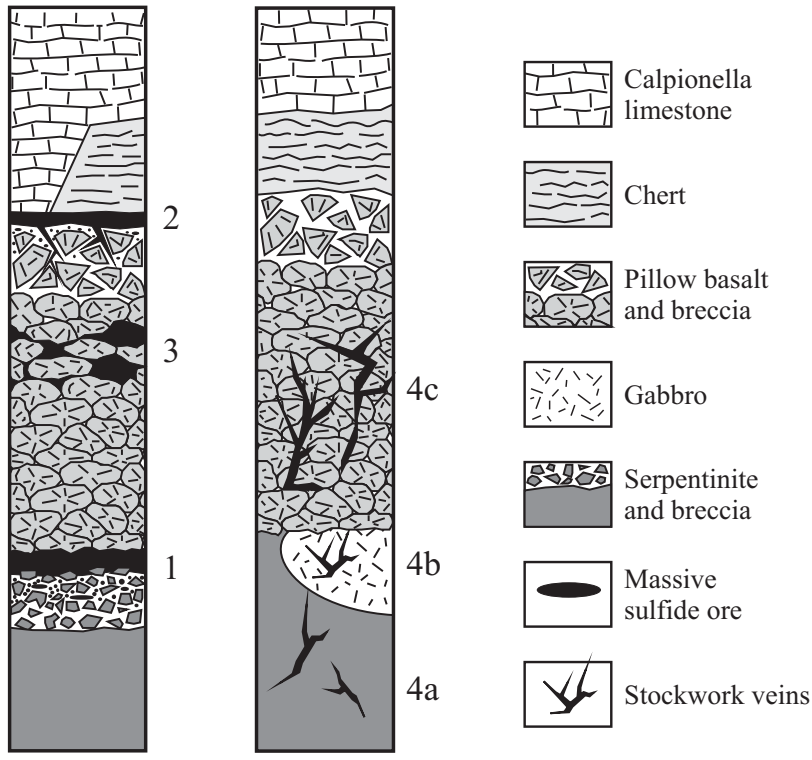

Figure 6. Schematic stratigraphy of the sulfide ore deposits in the northern Apennine ophiolites. 1) stratiform ore at the serpentinite breccia - pillow lava boundary (Monte Bardeneto, Reppia I, Monte Bianco I). 2) stratiform ore between the volcanic pile and the sedimentary cover (Reppia II, Corchia). 3) stratabound deposit within pillow basalt (Libiola). 4) stockwork-vein sulfide deposits in: a) serpentinite (Vigonzano, Ferriere, Groppallo, Santa Maria), b) gabbro (Campegli), and c) pillow basalt (Casali, Reppia III, Monte Bianco II, Boccassuolo, Montecreto). Redrawn after: Ferrario and Garuti (1980), Garuti and Zaccarini (2005), Zaccarini and Garuti (in press).
Garuti et al.

micritic limestone. Notably, basalt fragments are absent, and the ultramafic blocks are surrounded by a carbonatesiliciclastic sandy matrix showing widespread evidence of sedimentary graded bedding (Ferrario and Garuti, 1980). The size of blocks increases and the amount of interstitial matrix decreases toward the lower contact with massive serpentinite.

The sulfide ore occurs at the top of the ultramafic breccia and consists of a discontinuous tabular body extended up to more than a hundred meters along strike (Figure 10). The ore ranges from fairly massive ( $20 \mathrm{wt} \%$ total $\mathrm{S})$ at the contact with the hanging-wall pillow lava, to highgrade disseminated sulfide ( $<10 \mathrm{wt} \%$ total $\mathrm{S})$ toward the serpentinite footwall. The mineralized horizon reaches a total thickness of 2-4 meters in the most favorable cases. Pyrrhotite and chalcopyrite are early sulfides generally overgrown or replaced by pyrite with minor sphalerite, and magnetite. Gold and uraninite have been observed included in the sulfides (Garuti and Zaccarini, 2005; Zaccarini 2006). The ore gangue consists of a sandy matrix mainly composed of quartz (Monte Bianco) or calcite (Monte Bardeneto) usually accompanied by chlorite, and siderite. Textures predominantly reflect primary deposition of sulfides followed by grain coarsening and replacement biogenic material or bacteria-controlled precipitation of sulfides (framboids, algae filaments, shells of microfossils). Isolated grains of serpentine, clay minerals and chr-

Table 1. Representative compositions of sulfide ore from VMS of the northern Apennine ophiolites.

\begin{tabular}{|c|c|c|c|c|c|c|c|c|c|c|c|c|}
\hline & Ore assemblage & Gangue assembage & $\underset{(w t \%)}{S}$ & $\underset{(\mathbf{w t} \%)}{\mathrm{Cu}}$ & $\underset{(\mathbf{p p m})}{\mathbf{Z n}}$ & $\underset{(\mathbf{p p m})}{\mathbf{P b}}$ & $\underset{(\mathbf{p p b})}{\mathbf{A u}}$ & $\underset{(\mathbf{p p b})}{\mathbf{A g}}$ & $\underset{(\mathbf{p p m})}{\mathbf{N i}}$ & $\underset{(\mathbf{p p m})}{\text { Co }}$ & $\underset{(\mathbf{p p m})}{\mathbf{A s}}$ & $\underset{(\mathbf{p p m})}{\mathbf{U}}$ \\
\hline \multicolumn{13}{|c|}{ Type 1) Stratiform deposits in serpentinite breccia covered by pillow lava } \\
\hline Monte Bardeneto & Py-Po-Cp-(Sph)-Au-(Chr) & Qz-Cal-Sid-Chl-Serp & 18.3 & 1.6 & 413 & 1.3 & 689 & 700 & 533 & 532 & 36 & 2.66 \\
\hline Monte Bianco 1 & Py-Cp-Sph & Qz-Alb-Chl & 24.7 & 0.7 & 92 & 71 & 159 & 3200 & 62 & 125 & 50 & \\
\hline Reppia 1 & Py-Po-Cp-Au-(Chr) & Qz-Cal-Sid-Chl-Serp & 17.1 & 2.85 & 341 & & 287 & 833 & 693 & 2275 & 5.5 & 1.1 \\
\hline \multicolumn{13}{|c|}{ Type 2) Stratiform deposits in basalt breccia covered by pelagic sediments } \\
\hline Reppia 2 & Py-Cp-Po-Sph-Au & Qz-Cal-Sid-Chl & 19.8 & 0.93 & 88 & & 792 & 1063 & 129 & 347 & 63 & \\
\hline \multirow[t]{2}{*}{ Corchia } & Py-Cp-(Sph)-Au-U & Qz-Cal-Sid-Chl & 20.2 & 4.68 & 1329 & 53 & 1703 & 7726 & 1372 & 3240 & 147 & 3 \\
\hline & Sph-Py-(Gn-Fr) & Qz-Cal-Sid-Chl & 19.1 & 0.36 & 21850 & 221 & \multicolumn{2}{|c|}{47105597} & 96 & 1360 & 51 & \\
\hline \multicolumn{13}{|c|}{ Type 3) Stratabounnd deposits in pillow basalt } \\
\hline Libiola & Py-Cp-Sph & Qz-Cal-Chl & 19.1 & 2.48 & 2595 & 6.75 & 321 & 5046 & 42 & 307 & 25 & 5.52 \\
\hline \multicolumn{13}{|c|}{ Type 4a) Stockwork veins in serpentinite } \\
\hline Ferriere & Py-Po-Cp-(Chr) & Qz-Cal-Sid & 9.96 & 8.69 & 632 & & 80 & 5300 & 511 & 401 & 7.4 & 2.1 \\
\hline Vigonzano & Py-Cp-Po-(Chr) & Qz-Chl-Serp & 15.9 & 1.21 & 187 & 1.88 & 38 & 4328 & 381 & 312 & 2.26 & \\
\hline \multicolumn{13}{|c|}{ Type 4b) Stockwork veins in gabbro } \\
\hline Campegli & Py-Cp-Sph & Qz-Alb-Chl & 4.6 & 2.96 & 1143 & & 21 & 7800 & 37 & 47 & 1.8 & \\
\hline \multicolumn{13}{|c|}{ Type 4c) Stockwork veins in basalt and basalt breccia } \\
\hline Boccassuolo & Py-Cp-Sph-(Po-Gn) & Qz-Cal-Ep-Chl-Ti & 5.31 & 1.92 & 16151 & 21 & 12 & 4232 & 30 & 72 & 28 & \\
\hline Montecreto & Py-Cp-Sph-(Chr) & Qz-Cal-Chl & 4.73 & 0.39 & 117 & 4.08 & 7 & 400 & 277 & 47 & 4.02 & \\
\hline \multicolumn{13}{|l|}{ Casali-Monte } \\
\hline Loreto & Py-Cp-Sph & Qz-Alb-Chl & 1.71 & 1.61 & 378 & & & 700 & 50 & 26 & 1.9 & \\
\hline \multirow[t]{2}{*}{ Reppia 3} & Cp-Py & Qz-Chl & 2.32 & 2.19 & 127 & & 9 & 1000 & 25 & 54 & 1.5 & \\
\hline & Py-Cp & Qz-Chl & 19.5 & 19.8 & 1110 & & 141 & 4200 & 48 & 507 & 10 & \\
\hline Monte Bianco 2 & Рy-(Cp-Sph) & Qz-Cal-Sid-Chl-Serp & 0.75 & 0.58 & 38 & & 5 & & 24 & 61 & 1.7 & 1.3 \\
\hline
\end{tabular}



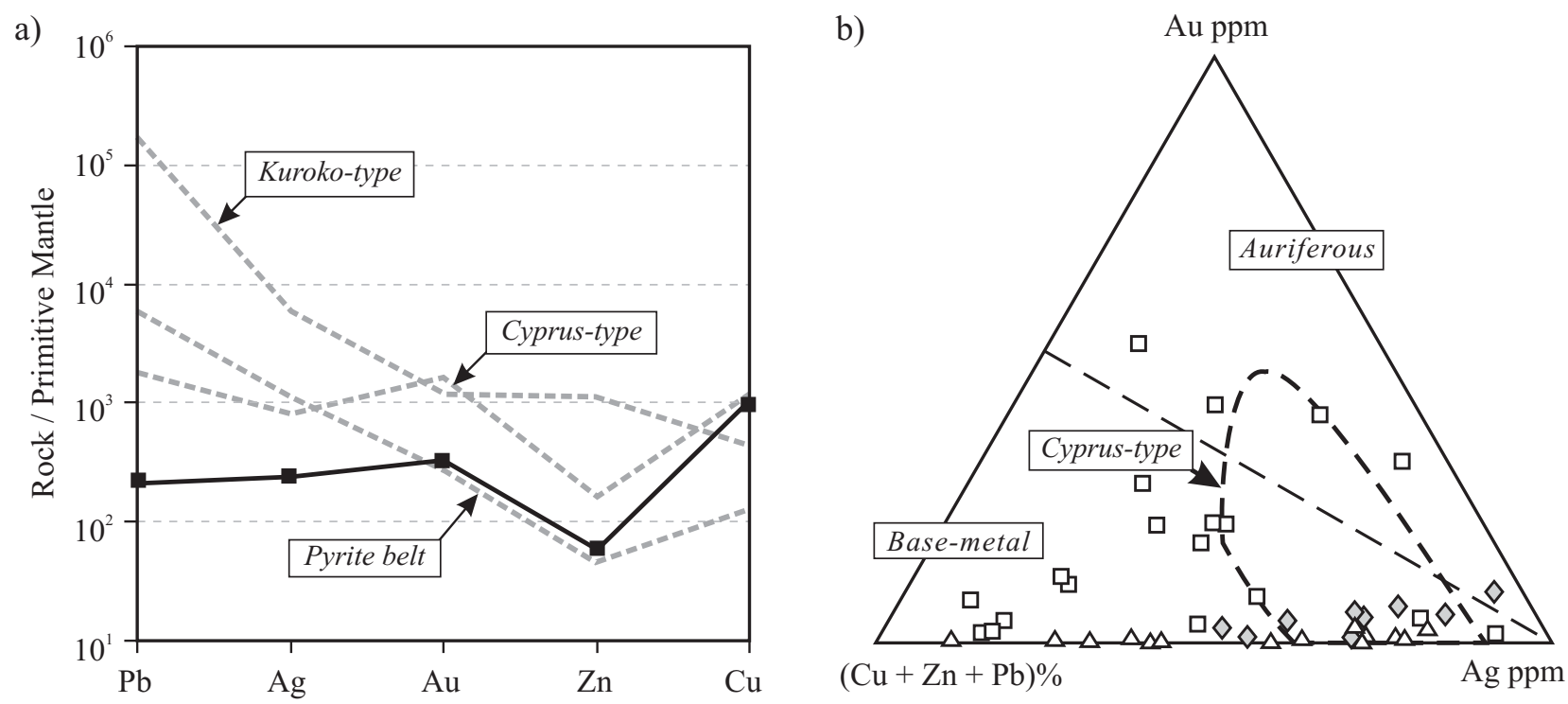

Figure 7. a) Primitive-mantle normalized average pattern of $\mathrm{Pb}, \mathrm{Ag}, \mathrm{Au}, \mathrm{Zn}$ and $\mathrm{Cu}$ for the northern Apennine sulfide deposits (black square) compared with diagrams for Cyprus-type, Kuroko-type and Pyrite-belt deposits. b) Triangular plot of $\mathrm{Au}-\mathrm{Ag}-(\mathrm{Cu}+\mathrm{Zn}+\mathrm{Pb})$ for VMS deposits of the northern Apennines. Fields for Cyprus-type deposits are shown for comparison; open square: stratiform ores; triangle: stockwork veins; gray diamond: stratabound ore. Data for the northern Apennine are from Zaccarini and Garuti (2005, in press); Data for VMS deposits from Barrie and Hannington (1999), Galley and Koski (1999).

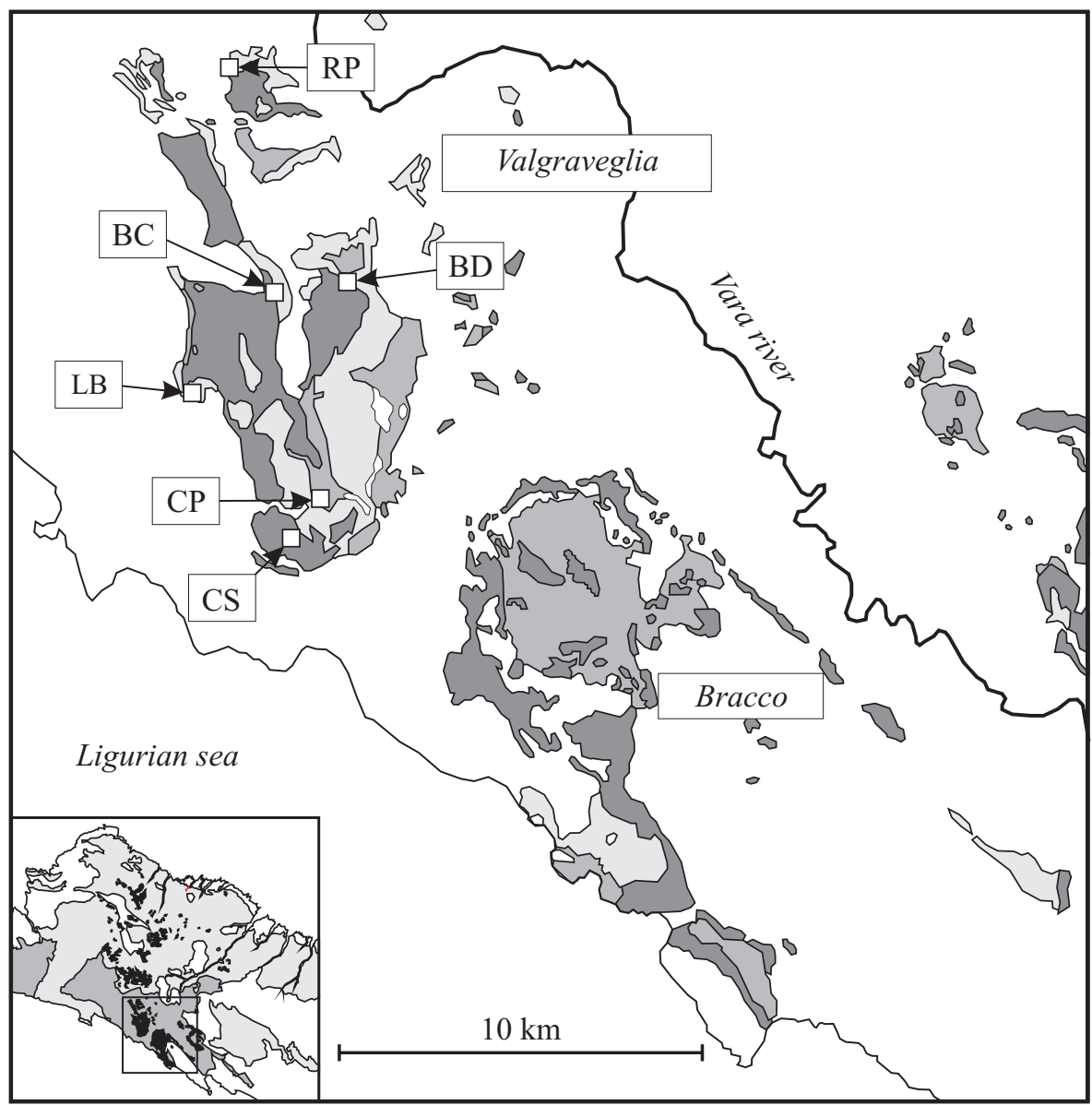

Figure 8. Geological sketch map of ophiolites in the Internal Ligurides (after Pagani et al., 1972) and location of relevant sulfide deposits (after Brigo and Ferrario, 1974; Ferrario and Garuti, 1980). Black: serpentinite, dark grey: gabbro, light grey: pillow basalt (see Figure 5 for dashed areas in the small frame) $\mathrm{RP}=$ Reppia, $\mathrm{BC}=$ Monte Bianco, $\mathrm{BD}=$ Monte Bardeneto, $\mathrm{LB}=$ Libiola, $\mathrm{CP}=$ Campegli, $\mathrm{CS}=$ Casali-Monte Loreto (see Table 1 for geographic coordinates of the deposits). 
Table 2. Type and location of the major VMS deposits in the Internal Ligurides.

\begin{tabular}{|c|c|c|c|}
\hline \multicolumn{2}{|l|}{ Locality } & \multicolumn{2}{|c|}{ GPS coordinates } \\
\hline \multicolumn{4}{|c|}{ Type 1) Stratiform deposits in serpentinite breccia covered by pillow lava } \\
\hline Monte Bardeneto & Main adit, alt. $778 \mathrm{~m}$ & N $44^{\circ} 20^{\prime} 376$ & E $09^{\circ} 29^{\prime} 400$ \\
\hline Monte Bianco & outcrop, alt. 500m & $\mathrm{N} 44^{\circ} 20^{\prime} 038$ & E $09^{\circ} 28^{\prime} 181$ \\
\hline Reppia 1 & Main dump, alt. $625 \mathrm{~m}$ & $\mathrm{~N} 44^{\circ} 22^{\prime} 905$ & E $09^{\circ} 27^{\prime} 451$ \\
\hline \multicolumn{4}{|c|}{ Type 2) Stratiform deposits in basalt breccia covered by pelagic sediments } \\
\hline Reppia 2 & Trench on the road, alt. $845 \mathrm{~m}$ & $\mathrm{~N} 44^{\circ} 23^{\prime} 228$ & E $09^{\circ} 27^{\prime} 392$ \\
\hline \multicolumn{4}{|c|}{ Type 3) Stratabounnd deposits in pillow basalt } \\
\hline Libiola & Open pit & $\mathrm{N} 44^{\circ} 18^{\prime} 240$ & E $09^{\circ} 26^{\prime} 938$ \\
\hline \multicolumn{4}{|c|}{ Type 4c) Stockwork veins in basalt } \\
\hline Casali-Monte Loreto & Adit, alt. $355 \mathrm{~m}$ & $\mathrm{~N} 44^{\circ} 16^{\prime} 229$ & E $09^{\circ} 29^{\prime} 690$ \\
\hline \multicolumn{4}{|c|}{ Type 4b) Stockwork veins in gabbro } \\
\hline Campegli & Prospect, alt. $250 \mathrm{~m}$ & $\mathrm{~N} 44^{\circ} 16^{\prime} 909$ & E $09^{\circ} 29^{\prime} 330$ \\
\hline
\end{tabular}

omite occur associated with the sulfide ore, and have been interpreted as detrital material and products of alteration derived from the ultramafic breccia (Garuti and Zaccarini, 2005; Zaccarini, 2006). Large crystals of zircon of probable detrital origin, also occur embedded in the carbonate matrix of the sulfide ore.

\subsection{The Reppia mining area}

The Reppia mining area is located about $1 \mathrm{~km}$ north of the Reppia village, in the northernmost edge of the Valgraveglia ophiolite block. This area is particularly interesting since it contains three different types of sulfide deposits within a single cross section exposed, between the localities of Cascina Arbaro and Cascina Cantalia (Figure 11). The sequence is analogous to the Monte BardenetoMonte Bianco area, although exposed in upright position, with the chert horizon reduced to a couple of meters in thickness. The lowermost deposit close to Cascina Arbaro is of type 1, and has structural and mineralogical characters similar to those of Monte Bardeneto and Monte Bianco. Pyrrhotite is a major component of the sulfide assemblage. Abundant detrital chromite occurs in the sulfide ore, whereas gold and uraninite are less frequent. The deposit is covered by pillow-lavas with a thickness of about 150 meters. Near Cascine Cantalia, the pillow-lavas are covered with breccia that hosts a stratiform sulfide deposit of type 2, in upper contact with chert passing upward into Calpionella limestone (Figure 12). The tabular ore body is up to 1 meter thick. It consists of fine-grained massive sulfide (20-25 wt\% total S) in contact with the sediments and becomes disseminated downward. The ore predominantly consists of pyrite, with subordinate chalcopyrite and accessory pyrrhotite, sphalerite and magnetite within a gangue of calcite, quartz, chlorite, siderite, clay minerals and sand-size fragments of basalt and chert. Pyrite may occur as framboids and replacement of organic matter (algae, shells). Gold and uraninite are occasional accessory minerals, whereas chromian spinel is absent (Garuti and Zaccarini, 2005).

A stockwork vein deposit lies under the stratiform ore, emplaced in the footwall basalt breccia (type 4c). Pyrite and chalcopyrite occur as a low-grade dissemination in a gangue of quartz and chlorite, with minor calcite. Relationships between stratiform and stockwork ore are unclear, because of the presence of syn-orogenic tectonic dislocations. However, the veins are likely to represent the sub-seafloor feeders of the stratiform ore (Ferrario and Garuti, 1980).

\subsection{The Libiola mine}

The mining site of Libiola is located on the west boundary of the Valgraveglia ophiolite complex (Fig 8), about $6 \mathrm{~km}$ northeast of Sestri Levante. Libiola was the biggest mine in the eastern Liguria district and probably the most productive in the northern Apennine, having supplied more than 1.5 Mt of ore with an average grade of 7 wt\% Cu between 1864 and 1961, when it was definitively closed (Galli and Penco, 1996).

The sulfide deposit consists of a suite of massive sulfide lenses (25-35 wt\% total S) stacked one on the other at the top of a huge dome of pillow basalt, underlain and partly overthrust by massive serpentinite and laminated gabbro (Figure 13). At the footwall of massive orebodies, the sulfide "infiltrates" among pillows and pillow-breccia fragments, giving rise to an interstitial ore $(<10 \mathrm{wt} \%$ total $\mathrm{S}$ ) that grades into a network of millimetric veins, filling cracks and fissures within completely chloritized basalt (stringer ore). The sulfide assemblage is dominated by pyrite and chalcopyrite with subordinate sphalerite and pyrrhotite, in a gangue of quartz, calcite and chlorite. 
Monte Bardeneto-Monte Bianco
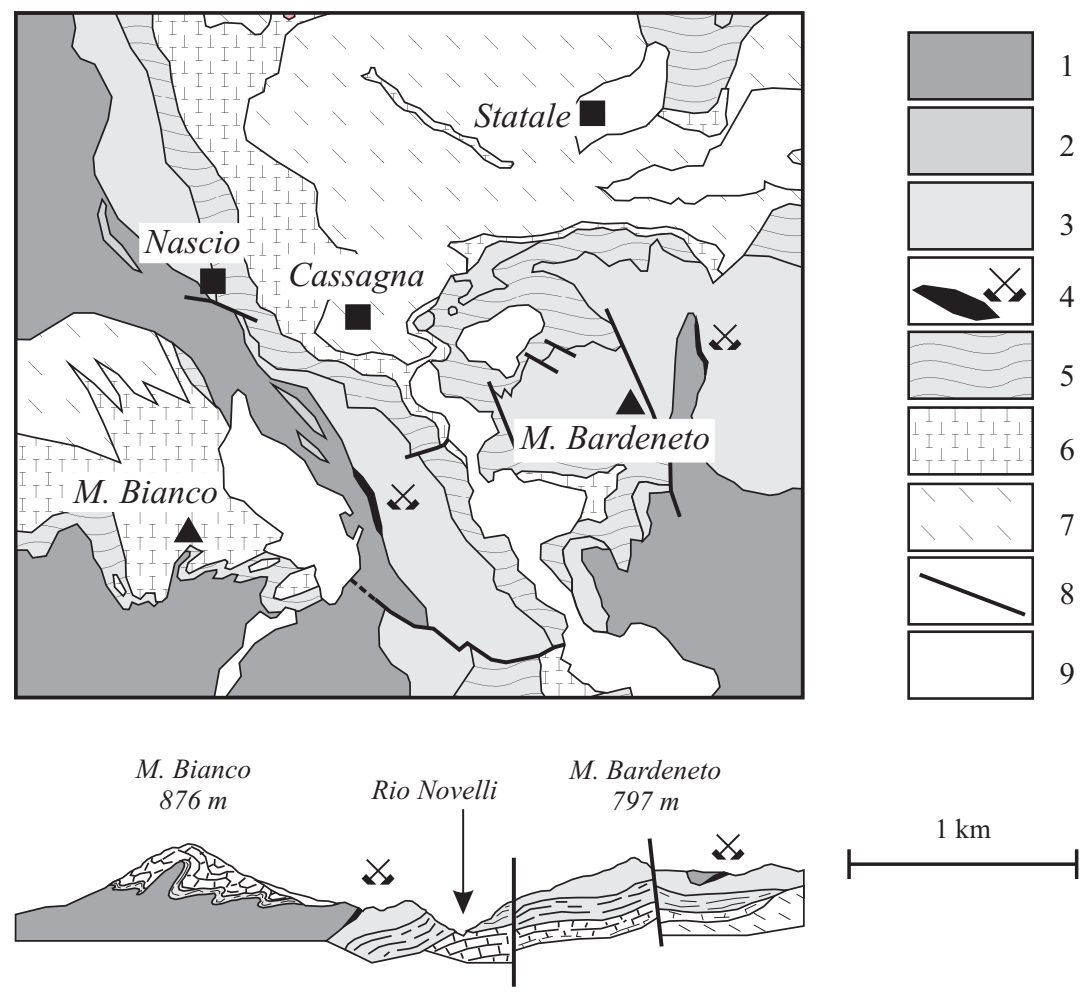

Figure 9. Geological sketch map and crosssection of type 1 sulfide deposits at M. Bianco and M. Bardeneto (after Decandia and Elter 1972). Symbols: 1 $=$ serpentinite and serpentinite breccia, $2=$ gabbro, $3=$ pillow basalt and basalt breccia, $4=$ sulfide deposit and mining works, $5=$ chert, $6=$ Calpionella limestone, 7 = Palombini shale, $8=$ main faults, 9 = quaternary cover.

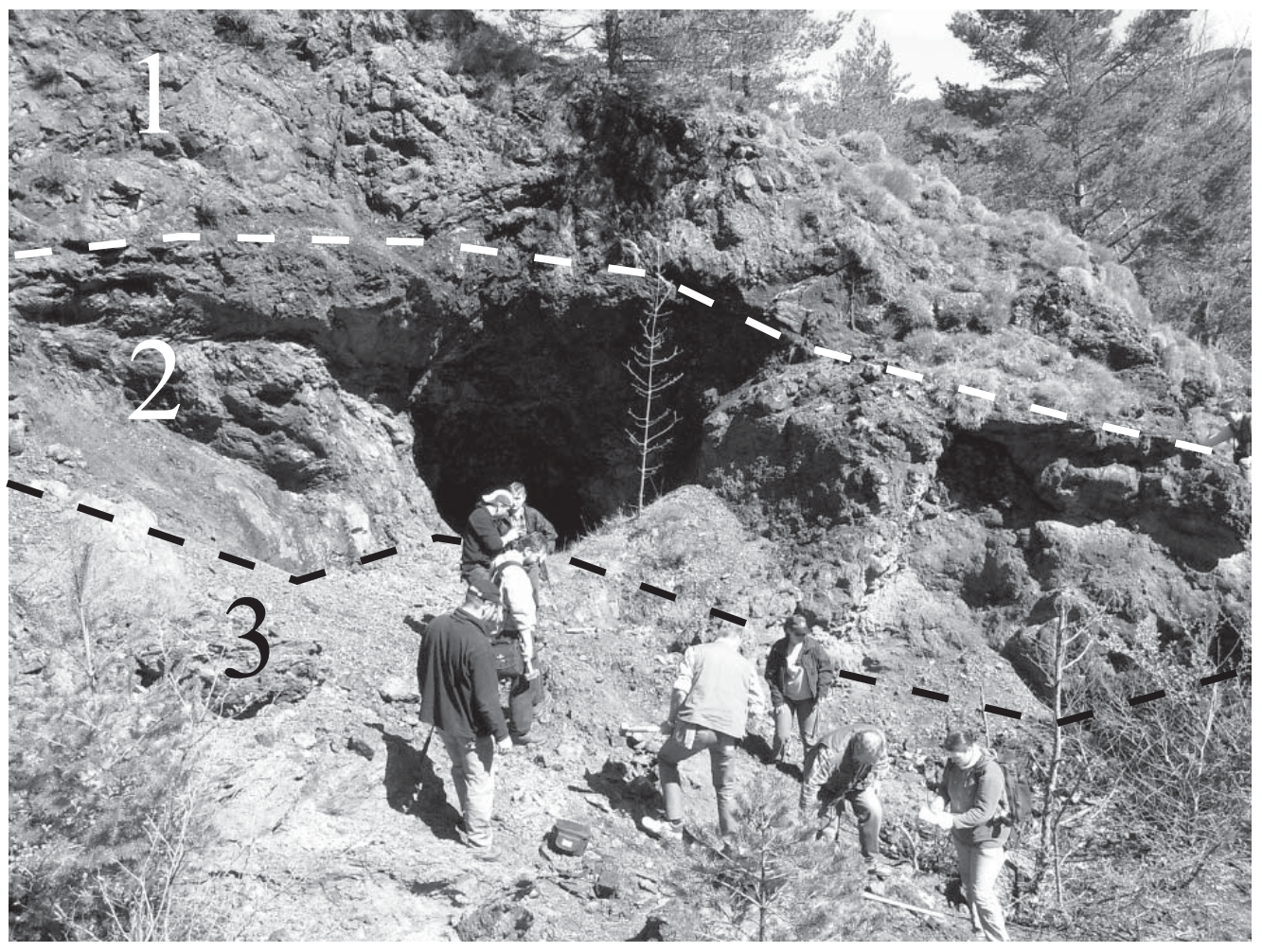

Figure 10. Field view of mining works at M. Bardeneto. 1) serpentinite breccia, 2) massive and disseminated sulfide ore, 3) pillow basalt. (photo Garuti, 2004). 


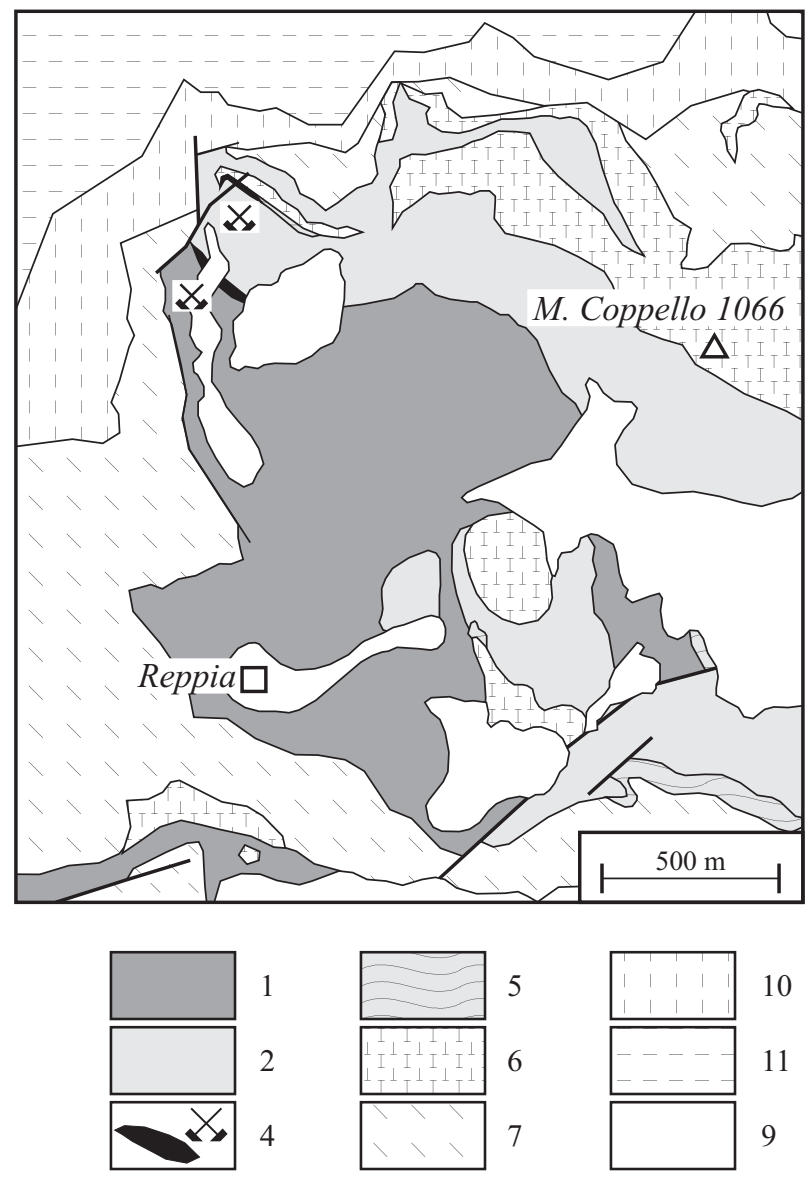

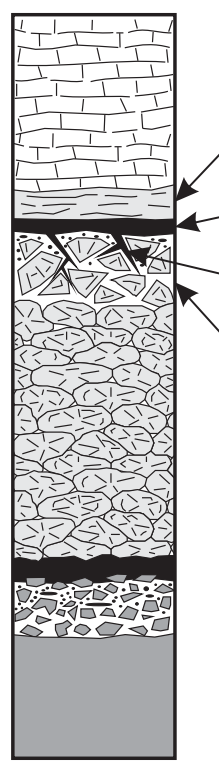

Sulfide ore (type 1)

Serpentinite breccia

Serpentinite

Reppia

Figure 11. Geological sketch map (after Decandia and Elter, 1972) and ideal stratigraphy of type-1, type-2 and type-4c sulfide deposits (after Garuti and Zaccarini, 2005) in the Reppia area. $10=$ shales, $11=$ flysch, other symbols as in Figure 9.

The biogenic features observed in stratiform deposits are absent, although pyrite framboids have been observed in several samples. Ilmenite, rutile, and titanite occur in the chlorite gangue of the stringers. Gold and silver minerals have been reported to be relatively common (Galli, 1959; Ferrario and Garuti, 1980) frequently accompanied by uraninite (Garuti and Zaccarini, 2005). A second type of very low grade mineralization occurs associated with shear zones in serpentinite, possibly representing syn-tectonic remobilization of magmatic sulfides, as indicated by the occurrence of accessory pentlandite (Bertolani, 1952).

\subsection{The Campegli-Casali-Monte Loreto mining area}

The Campegli-Casali-Monte Loreto mining area is located at the southernmost edge of the Valgraveglia ophiolite complex, (Figure 8). Here, stratigraphic sections showing transition from the mantle peridotite-gabbro basement to the pillow-lava are exposed at several localities. At Monte Loreto, pillow basalt overlays serpentinized mantle tectonite, whereas to the north, in the area of Campegli, they cover a huge body of gabbro (Figure 14). The transition is marked by an erosion surface in both cases, indicating that the peridotite-gabbro basement was exposed onto the seafloor for a long time before outflow of pillow basalt. The occurrence of ophicalcite breccia and hematitized soils at the top of serpentinite and gabbro support this assumption (Ferrario and Garuti, 1980). Two types of stockwork vein deposits are known in the area.

At Monte Loreto a huge pillow-lava flow is crosscut by a vertical network of quartz and calcite veins containing low grade sulfide mineralization, typically yielding 2-5 wt\% total S (Bertolani, 1952). The stockwork (type 4c) is probably more than 100 meters wide, and extends from the locality Casali (90m a.s.l.) up to nearby the top of Monte Loreto (359m a.s.1.). This deposit has been mined probably since the Roman times, and is reported to contain veins of metric size, exposed in underground works, having highgrade and massive $\mathrm{Cu}$ mineralization, accompanied by gold (see references in Galli and Penco, 1996). The sulfide assemblage consists of chalcopyrite and pyrite in variable proportions with non ubiquitous sphalerite and magnetite (Bertolani, 1952). The low-grade sulfide ore usually forms irregular patches up 1 centimeter in size, disseminated in a gangue of quartz and green chlorite forming minute 


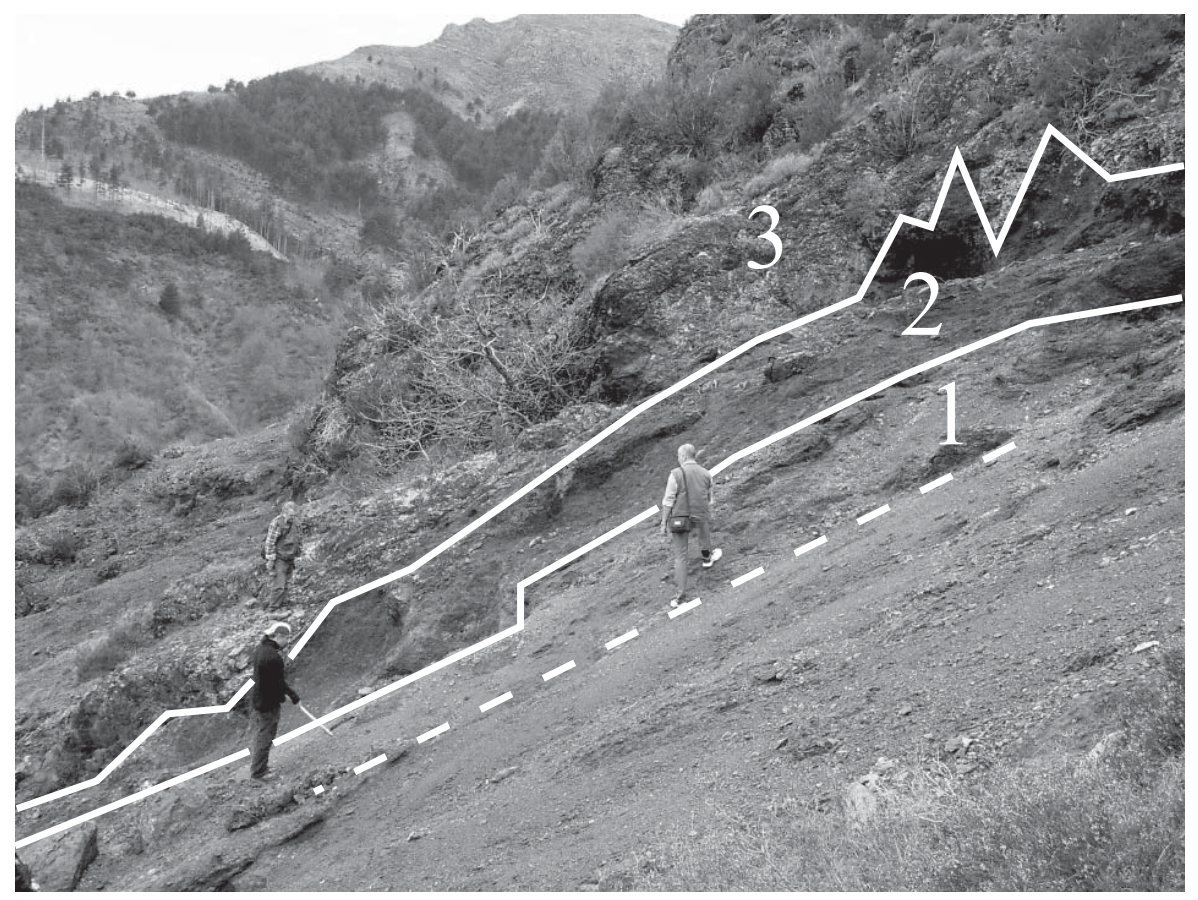

Figure 12. Field view of the Reppia type-2 sulfide deposit. 1) massive sulfide ore at the top of pillow basalt breccia, 2) chert, 3) Calpionella limestone. (photo Garuti, 2004).

vermicular intergrowth with quartz. Epidote and titanite are common accessory phases of the gangue assemblage (Zaccarini, 2006; Zaccarini and Garuti, in press).

The second type of stockwork deposit is located about 150 meters from the village of Campegli, and represents stockwork veins emplaced into massive gabbro (type $4 b$ ). All of the deposits of this type (i.e.: Piazza, Bargone, Molin Cornaio, Monte Mesco) are small and low-grade. At Campegli, an assay gallery cuts across a small stockwork of vertical veins with low-grade sulfide mineralization $(<5$ wt $\%$ total S). The ore consists of chalcopyrite, pyrite and sphalerite, in decreasing order of abundance, disseminated in a gangue of quartz and chlorite, with abundant epidote and titanite.

In all these stockwork deposits, the sulfides are characterized by idiomorphic to sub-idiomorphic shapes, indicating precipitation and grain coarsening under hydrothermal conditions. Textural evidence for replacement of biological material or interaction with fresh seawater in the seafloor environment is absent (Zaccarini and Garuti, in press).

\section{Sulfide deposits in the External Ligurides}

The ophiolite complexes of the External Ligurides are spread along the northern Apennine chain, over a distance of more than $150 \mathrm{~km}$. Relevant deposits occur in the mountain territories of western and central Emilia Romagna. The type and location of major ore deposits of the External Ligurides are summarized in Table 3.
5.1 The Vigonzano-Groppallo-Ferriere district (western Emilia Romagna)

Several ophiolite massifs occur in the high valley of the Nure river. Those containing relevant sulfide deposits are located near Farini d'Olmo, where, separated blocks of serpentinite and spilitic basalt occur embedded in the sedimentary mélange, spread over an area of about 5 $x 7 \mathrm{~km}$ on both sides of the Nure river (Figure 15). The sulfide deposits consist of huge stockwork bodies exclusively hosted in serpentinite (type 4a) at the localities of Vigonzano, Groppallo and Ferriere. At Ferriere, the deposit has been known since the Roman times and was active for the extraction of iron in the $15^{\text {th }}$ century under the Signoria Sforza of Milan. In contrast, the two other deposits became known only in the second half of the $19^{\text {th }}$ century, although the main orebody, probably amounting up to $300,000 \mathrm{t}$ with an estimated grade of $3 \% \mathrm{wt} \mathrm{Cu}$, was discovered at Vigonzano only in 1956. Mining activities in the whole district lasted until the 1973, supplying $\mathrm{Cu}-\mathrm{Fe}$ sulfide and iron-oxide ore (magnetite, hematite).

Vigonzano - The mine of Vigonzano is the biggest deposit in the External Liguride ophiolites. Mining works (trenches and galleries) are still visible in three serpentinite blocks located north, west and southwest of the Vigonzano village, respectively (Figure 16). Bertolani (1959), who could enter the underground mining works when still active, reports that the major ore body, "Cantiere Vaie", is hosted in the northern serpentinite block (Figure 17). It consists of a several ten meters thick stockwork trending 


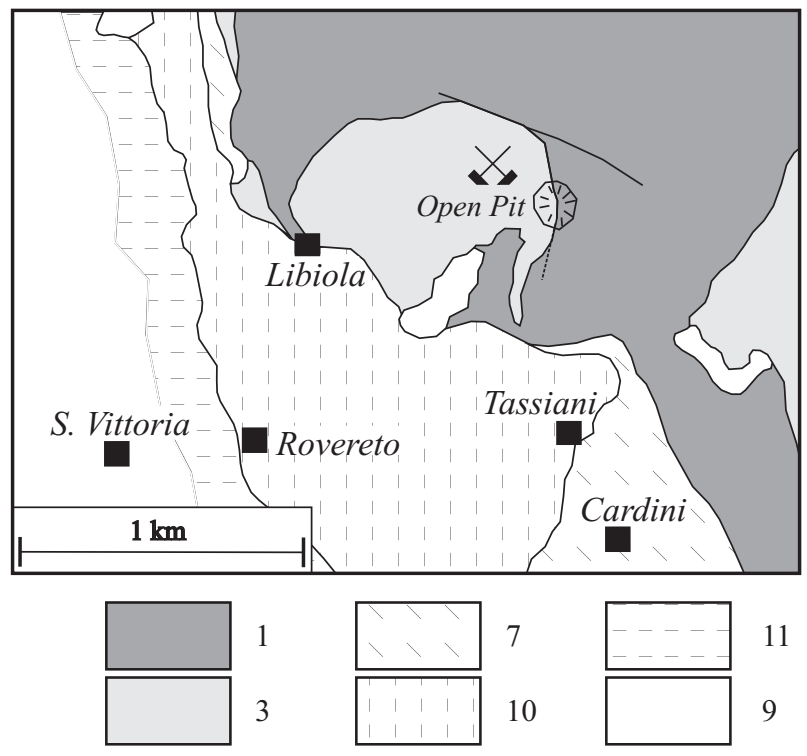

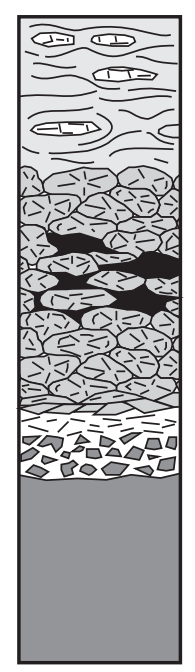

Shale and limestone

Sulfide ore (type 3)

Pillow basalt

Gabbro

Serpentinite breccia

Serpentinite

Libiola

Figure 13. Geological sketch map (after Decandia and Elter, 1972) and ideal stratigraphy (after Garuti and Zaccarini, 2005) of the type-3 sulfide deposit at Libiola. Location of the main open pit is indicated. Symbols as in Figures 9 and 11.

SW-NE and steeply dipping NW, below the sedimentary mélange. The mineralized veins increase in thickness up to more than 1 meter, toward the core of the stockwork. Veins and host serpentinite are locally brecciated and are abruptly cut by the contact with the sediments. In single veins, the ore/gangue ratio rapidly increases along strike up to form massive sulfide bodies crosscut the serpentinite. Microscopic study indicates that major ore minerals are pyrite, chalcopyrite, magnetite and hematite, along with accessory pyrrhotite, marcasite, and millerite. The ore minerals occur in a gangue of quartz, calcite, chlorite, siderite, with accessory apatite, zircon and chromian spinel. Bertolani (1959) reports that, locally, magnetite and hematite form workable orebodies in which $\mathrm{Cu}$-Fe sulfides occur as accessory phases. The iron-oxide ore was separated from the sulfide ore, and used in iron industry. Ironoxide ore stocked in the service areas of the Vigonzano mine was sampled and microscopically examined, revealing widespread occurrence of chromite relics at the core of magnetite-hematite aggregates.

Groppallo - The deposit of Groppallo is situated on the right side of the Nure river, in front of Vigonzano. It consists of mineralized stockwork veins emplaced within an isolated block of serpentinite. Other serpentinite blocks in the area appear to be barren or show only weak vein mineralization. The ore assemblage has the same characters as in Vigonzano, although the iron-oxide ore appears to be less abundant, judging from its scarcity in the mining dump.

Ferriere - The Italian word Ferriere literally means Iron Factories that clearly relates the name of this village with the crashing mill and foundry plant built in the $19^{\text {th }}$ century for ore treatment. Some old mines are located in a huge peak of serpentinite arising from the sedimentary mélange along the Grondana creek valley. Underground inspection reveals that the serpentinite is thrust over a coarse grained gabbro cut in its turn by subvertical basaltic dikes. To the west and north the serpentinite disappears under a thick horizon of Palombini shale, however it is exposed along the Grondana creek, suggesting extension below the sedimentary cover. This is supported, by occurrence of two collapsed galleries (Galleria delle Roncalle, and Cantiere degli Inglesi) entering the sedimentary cover, in front of which abundant ultramafic detritus is found.

The stockwork deposit occurs exclusively in the serpentinite and consists of quartz-carbonate-chlorite-siderite veins intensively mineralized with pyrite and chalcopyrite, and accessory pyrrhotite. At the top of the serpentinite peak, the stockwork is cut by sub-horizontal layers of Palombini shale, suggesting that the deposit was eroded before deposition of the pelagic sediments. At Ferriere the main ore is represented by massive lenses of iron oxides (magnetite and hematite) with accessory $\mathrm{Cu}-\mathrm{Fe}$ sulfides that are exposed in the east and southeast scarp of the serpentinite peak. Blocks of iron-oxide ore are very abundant in the dump of Galleria delle Roncalle, suggesting that this type of ore was considerably extended within the serpentinite body.

\subsection{The Corchia mining district}

Four major ophiolite blocks occur in the Taro valley, about $15 \mathrm{~km}$ east of Borgo Val di Taro (Figure 15). The sulfide deposits occur inside one of the most extended blocks, about 3.5 x $1.5 \mathrm{~km}$, near the Corchia village, on 

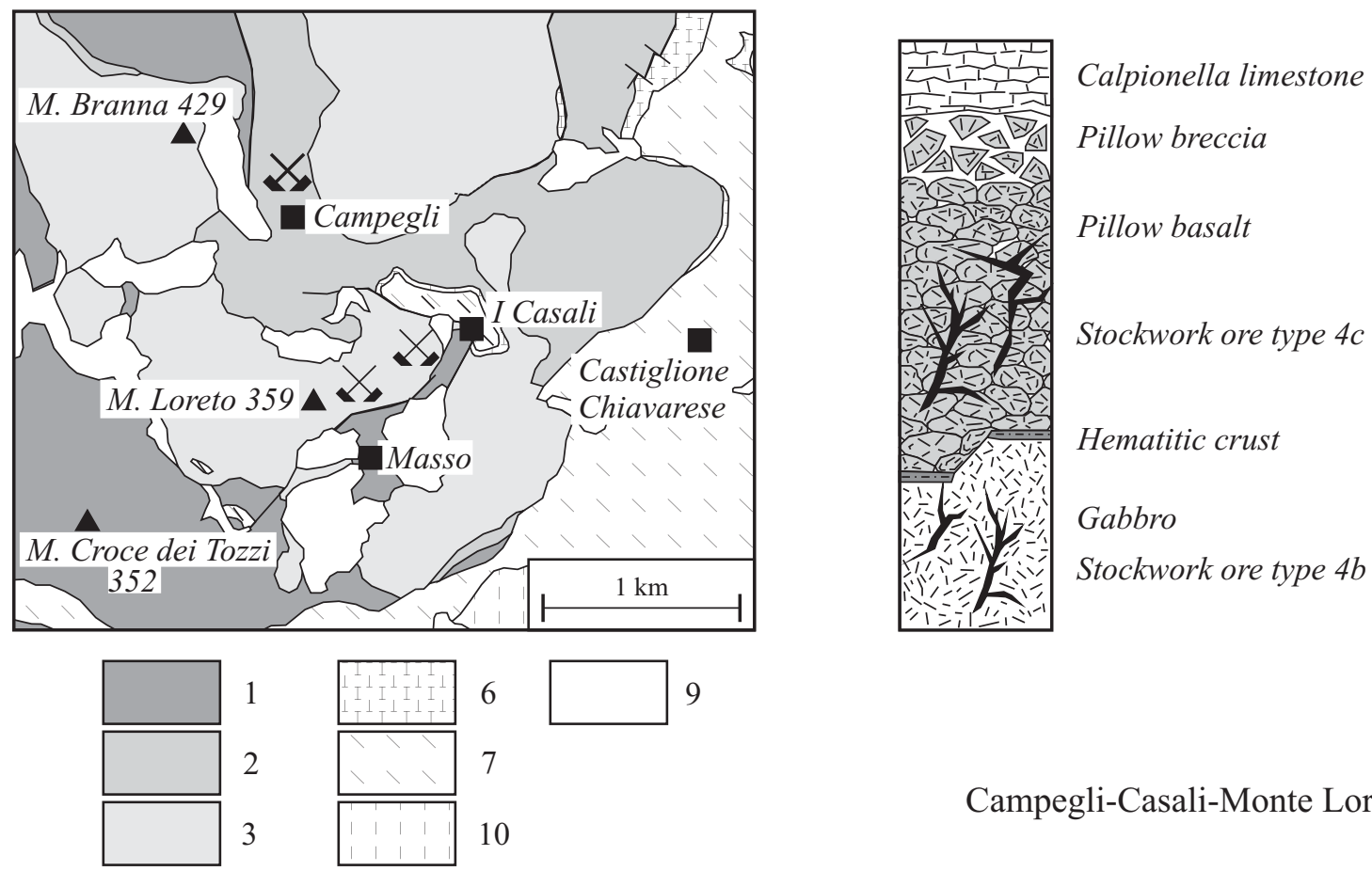

Figure 14. Geological sketch map (after Decandia and Elter, 1972) and ideal stratigraphy (after Ferrario and Garuti, 1980) of the type-4b and type-4c sulfide deposits at Campegli, and Casali-Monte Loreto. Symbols as in Figures 9 and 11.

Table 3. Type and location of the major VMS deposits of the External Ligurides.

\begin{tabular}{|c|c|c|}
\hline Locality & & GPS \\
\hline \multicolumn{3}{|c|}{ Type 2) Stratiform deposits in basalt breccia covered by pelagic sediments } \\
\hline \multirow[t]{2}{*}{ Corchia } & "Cantiere Donnini”, alt. 770m & $\mathrm{N} 44^{\circ} 29^{\prime} 780 \mathrm{E} 09^{\circ} 55^{\prime} 276$ \\
\hline & "Cantiere Speranza" & $\mathrm{N} 44^{\circ} 29^{\prime} 776$ E $09^{\circ} 55^{\prime} 272$ \\
\hline \multicolumn{3}{|c|}{ Type 4a) Stockwork veins in serpentinite } \\
\hline \multirow[t]{3}{*}{ Ferriere } & "Grondone" (gallery N ${ }^{\circ} 4$ ) & $\mathrm{N} 44^{\circ} 39^{\prime} 481$ E $09^{\circ} 28^{\prime} 952$ \\
\hline & "Grondone" (outcrop) alt. 860m & $\mathrm{N} 44^{\circ} 39^{\prime} 410$ E $09^{\circ} 28^{\prime} 916$ \\
\hline & Gallery "Roncalle", alt. $875 \mathrm{~m}$ & $\mathrm{~N} 44^{\circ} 39^{\prime} 690$ E $09^{\circ} 28^{\prime} 882$ \\
\hline Vigonzano & "Cantiere Vaie", alt. 785m & $\mathrm{N} 44^{\circ} 42^{\prime} 100$ E $09^{\circ} 31^{\prime} 828$ \\
\hline Groppallo & Main Trench, alt. $772 \mathrm{~m}$ & $\mathrm{~N} 44^{\circ} 42^{\prime} 240$ E $09^{\circ} 36^{\prime} 450$ \\
\hline \multicolumn{3}{|c|}{ Type 4b) Stockwork veins in basalt and basalt breccia } \\
\hline \multirow[t]{8}{*}{ Boccassuolo } & $\begin{array}{l}\text { Gallery "Labirintica", alt. } 704 \\
\text { "La Pioppaccia" (dump), alt. } 685 \mathrm{~m}\end{array}$ & $\mathrm{~N} 44^{\circ} 18^{\prime} 345$ E $10^{\circ} 37^{\prime} 173$ \\
\hline & "Miniera dei due livelli" & N $44^{\circ} 17^{\prime} 977$ E $10^{\circ} 37^{\prime} 171$ \\
\hline & Gallery "Dolicopoda", alt. 673 & $\mathrm{~N} 44^{\circ} 18^{\prime} 313$ E $10^{\circ} 37^{\prime} 141$ \\
\hline & Gallery "Pipistrello", alt. 673 & $\mathrm{~N} 44^{\circ} 18^{\prime} 321$ E $10^{\circ} 37^{\prime} 140$ \\
\hline & Prospect (a) "Le Lame", alt. 1030m & $\mathrm{N} 44^{\circ} 17^{\prime} 713$ E $10^{\circ} 37^{\prime} 854$ \\
\hline & Gallery “Allagata", alt. 663m & $\mathrm{N} 44^{\circ} 18^{\prime} 363$ E $10^{\circ} 37^{\prime} 127$ \\
\hline & Cinghi quarry, alt. $874 \mathrm{~m}$ & \\
\hline & "Filone Omar", alt. 880m & 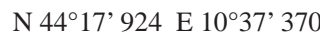 \\
\hline \multirow[t]{4}{*}{ Montecreto } & Gallery "Cà Marsiglio", alt. 620m & $\mathrm{N} 44^{\circ} 15^{\prime}, 969$ E $10^{\circ} 43^{\prime} 744$ \\
\hline & Gallery "Cà Gabriele", alt. 580m & $\mathrm{N} 44^{\circ} 15^{\prime} 912$ E $10^{\circ} 43^{\prime} 609$ \\
\hline & Gallery "Geotritoni", alt. 590m & $\mathrm{N} 44^{\circ} 16^{\prime} 096$ E $10^{\circ} 43^{\prime} 665$ \\
\hline & Gallery "Bosco Ceduo", alt. $565 \mathrm{~m}$ & $\mathrm{~N} 44^{\circ} 16^{\prime} 159$ E $10^{\circ} 43^{\prime} 638$ \\
\hline
\end{tabular}


the left bank of the Manubiola creek. The ophiolite consists of serpentinite and pillow basalt embedded in a sedimentary mélange of Calpionella limestone and Palombini shale. Unusual is the occurrence of huge granitic bodies tectonically overlying the ophiolitic rocks. The contacts between serpentinite and basalt generally indicate thrust of the mantle rocks onto the volcanic pile. However, the stratigraphic succession from serpentinite to pillow basalt and Palombini shale can be observed in the southeastern part of the Corchia ophiolite complex, where the major sulfide deposits are situated.

The first written document to proclaim the existence of $\mathrm{Cu}$-deposits in this area dates back to 1865 (Bertolani, personal communication). Exploration led to the discovery of two major deposits (Cantiere Donnini and Cantiere Speranza) that underwent alternate periods of exploitation between 1900 and 1943, when the mine was definitively closed. The deposits occur at the top of a huge pillow lava unit, and are covered with Palombini shale. The sulfide ore is usually massive at the contact with the hanging-wall sediments, and grades into a network of veins infiltrating the footwall pillow lava (Bertolani, 1962). These deposits represent the only known example of stratiform sulfides of type 2 in the External Ligurides (Garuti and Zaccarini, 2005).

An internal report of the "Società Industriale Mineraria del Rame" documenting the state of works on the $1^{\text {st }}$ May 1928, indicates that the ore body at Cantiere Speranza (Figure 18) consists of a massive sulfide layer steeply inclined $\left(\sim 70-80^{\circ}\right)$ southward, probably extended more than 100 meters along strike and 40 meters in depth, with a maximum thickness of about 5 meters (Adorni and Guelfi, 1997; Stuppini, 1998). The ore assemblage consists of pyrite and chalcopyrite with workable lenses of massive $\mathrm{Zn}$-Fe ore, mainly sphalerite with accessory pyrite. Gold and uraninite occur as microscopic inclusions in pyrite

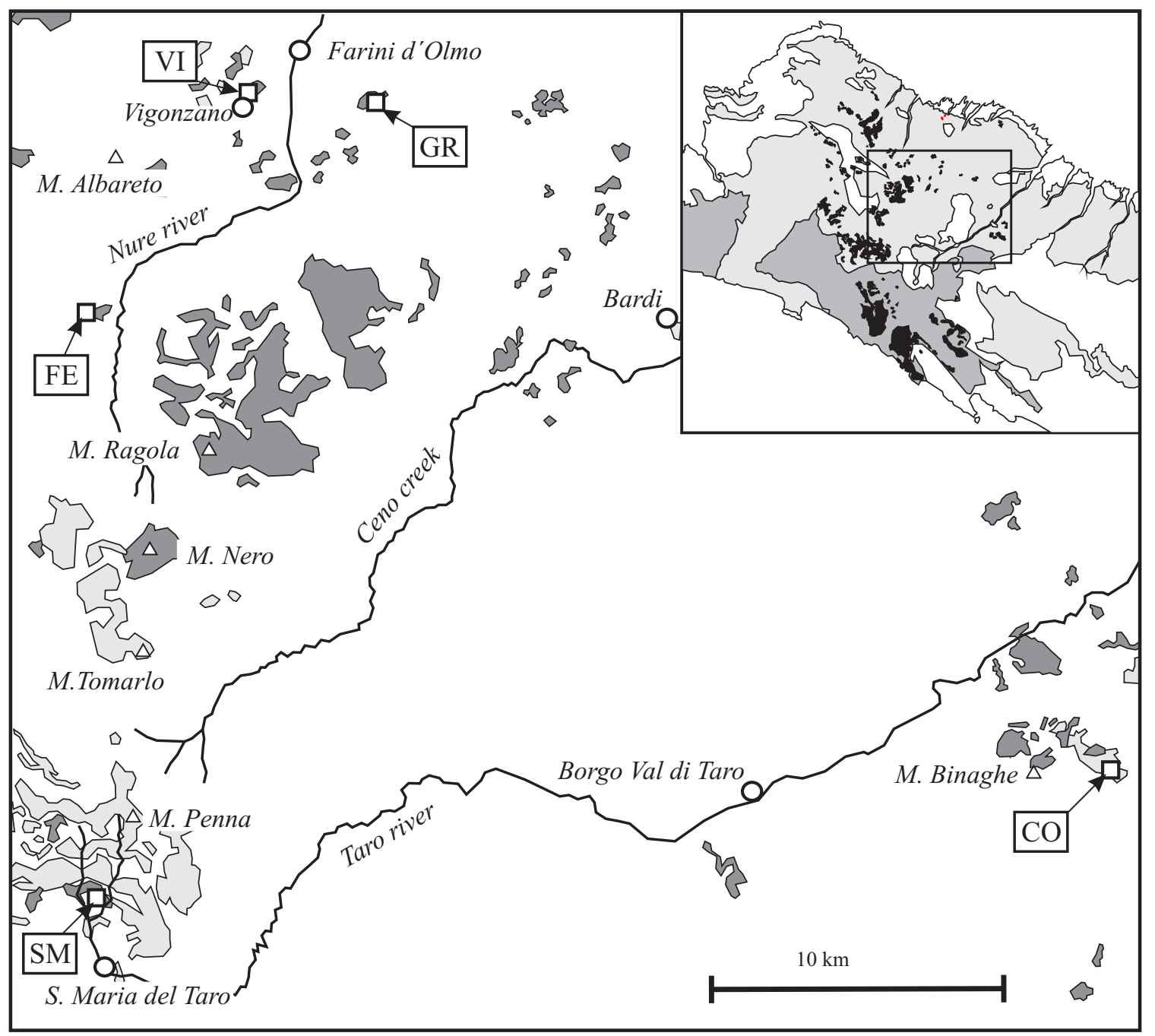

Figure 15. Geological sketch map of ophiolites in the External Ligurides of western Emilia Romagna (after Pagani et al., 1972) and location of relevant sulfide deposits (after Zaccarini and Garuti, in press). Black: serpentinite, light grey: pillow basalt (see Figure 5 for dashed areas in the small framework). $\mathrm{VI}=$ Vigonzano, $\mathrm{GR}=$ Groppallo, $\mathrm{FE}=$ Ferriere, $\mathrm{CO}=$ Corchia, $\mathrm{SM}=\mathrm{S}$. Maria del Taro. (see Table 3 for geographic coordinates of the deposits). 
Vigonzano

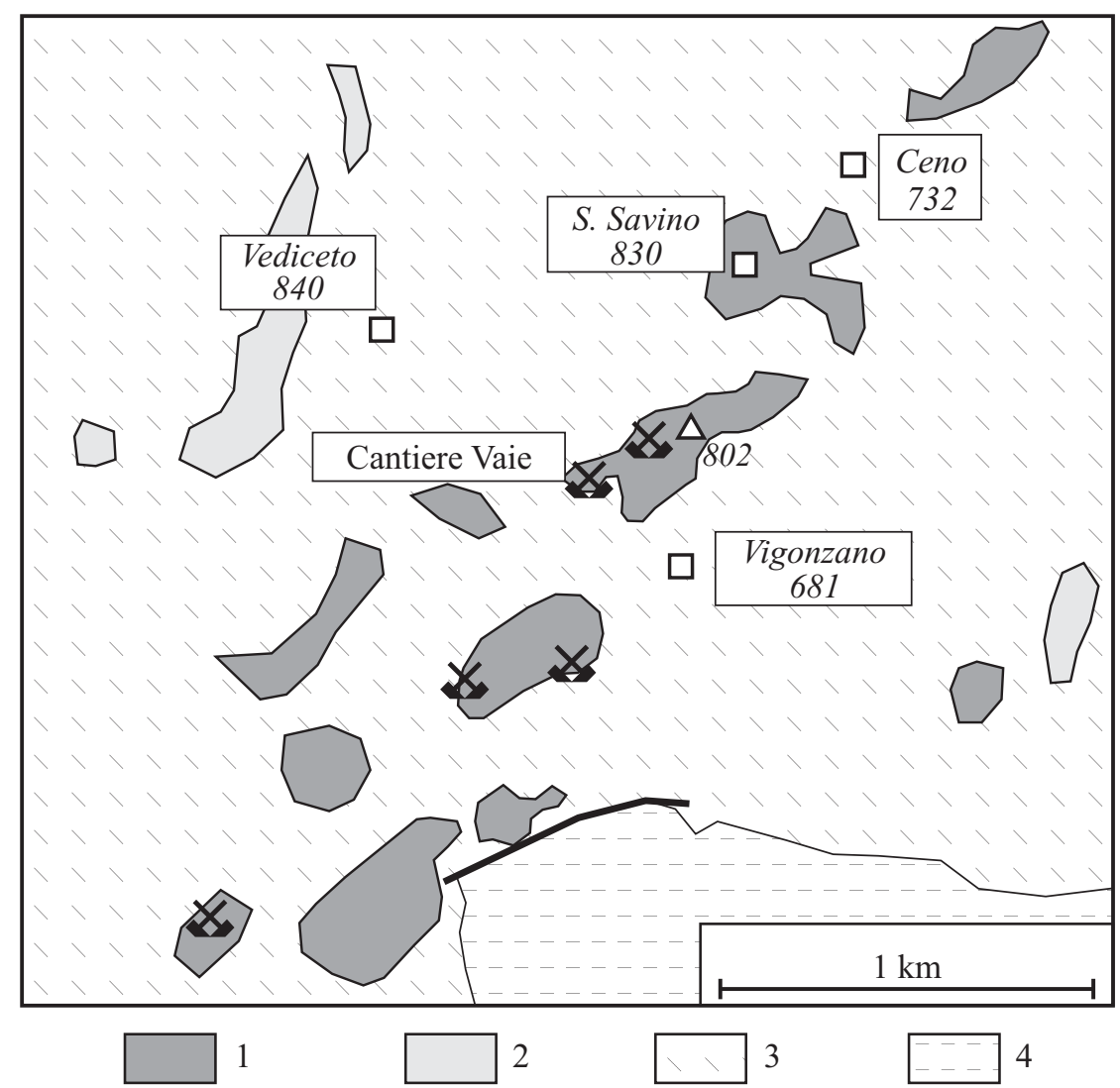

Figure 16. Geological sketch map of the type-4a sulfide deposits at Vigonzano, modified after Bertolani (1953). Symbols: $1=$ serpentinite and serpentinite breccia, 2 = basalt and basalt breccia, 3 = Sedimentary mélange, "Argille Scagliose". 4 = flysch. Other symbols as in Figure 9.

(Garuti and Zaccarini, 2005). These authors also describe microscopic textures of the massive sphalerite, possibly representing replacement of radiolarian shells or bacterial colonies. They report the occurrence of a variety of microscopic phases that accompany the $\mathrm{Zn}$-Fe sulfide ore (acanthite, freibergite, siderite, smithsonite, barite, $\mathrm{Fe}-\mathrm{Ca}$ sulfate, and the rare mineral hydroromarchite).

The orebody in "Cantiere Donnini" consists of an irregular lens of massive sulfide that was originally exposed at the surface and therefore covered with a thick gossan (Adorni and Guelfi, 1997; Garuti and Zaccarini, 2005). The gossan deposit was dug out completely in 1939, yielding some hundred tons of ore with 3-5 wt $\% \mathrm{Cu}$. The deposit is presently exposed in digging scarps and underground works that are still accessible (Figure 19). Both external and underground exposition show a massive sulfide bank (1-3 $\mathrm{m}$ thick) floored by pillow breccia and roofed by a mélange of limestone blocks in a clay matrix. The massive sulfide (pyrite, chalcopyrite with accessory sphalerite) is characterized by detrital texture in which angular fragments of sulfides occur in a ground mass of quartz, calcite, chlorite and clay minerals. Shells of microfossils replaced by sulfide, and anomalous concentrations of $\mathrm{Au}$ and $\mathrm{U}$ are common in this type of ore (Garuti and Zaccarini, 2005). The whole picture suggests that the sulfide ore underwent post-depositional reworking by submarine debris flow and accumulation in a topographic depression, followed by burial under a Palombini shale olistostrome.

\subsection{The Boccassuolo-Montecreto district (central Emilia Romagna)}

A review of the ophiolites in the External Ligurides domain within Modena and Reggio Emilia provinces (Figure 20) yielded more than 900 blocks associated with the Cretaceous sedimentary mélange, most of which are much less than 1 square kilometer in size (Bertolani and Capedri, 1966). Despite the high degree of fragmentation, these ophiolites underwent exploration since the Etruscan times (Violi Guidetti, 1968). Several deposits of small size were mined at Boccassuolo from the Middle Age to the early $19^{\text {th }}$ century. Systematic exploration in the thirties led to the discovery of an economic deposit at Montecreto where exploitation was undertaken and lasted in 1948.

Boccassuolo - The most extended ophiolite complex of 


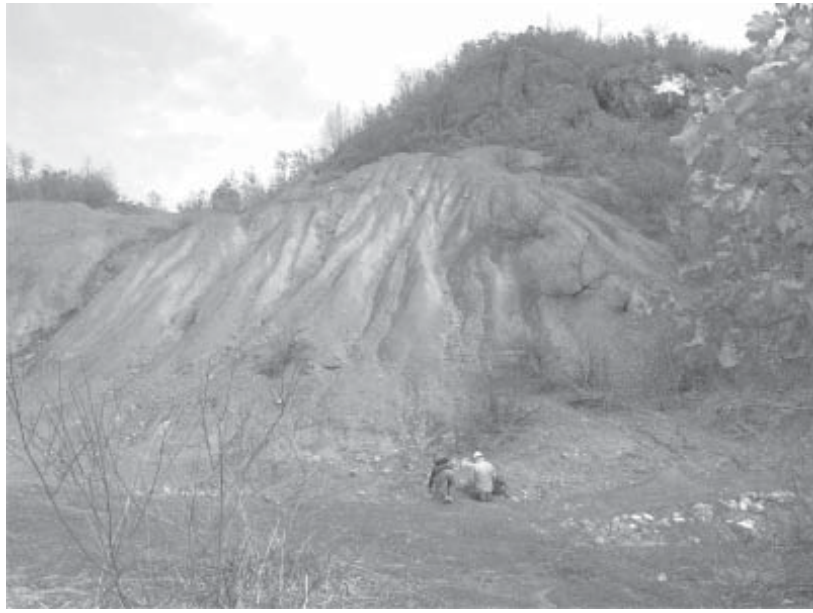

Figure 17. Field view of the huge dump in the "Cantiere Vaie" of the Vingonzano mine, where the 300,000 tons ore body was discovered in 1956. (photo Garuti, 2006).

central Emilia Romagna is located near the Boccassuolo village. It consists of two major blocks (Poggio Bianco Dragone and Cinghio del Corvo) and several minor ones (Poggio Medola, Madonna del Calvario, Boccassuolo, Sassatella) exposed along the Dragone valley (Figure 21). The ophiolite bodies as a whole cover about 3 x 1.5 kilometers, and are separated by a sub-vertical fault, with interposition of thin zone of sedimentary mélange consisting of Palombini shale and ophiolitic fragments. The Poggio-Bianco-Dragone block consists of pillow-lavas al- ternated with horizons of ophiolitic breccia and sandstone composed of fragments of basalt, limestone, chert, and rare granite (Figure 22). Thin layers of siltitic clays are intercalated in the breccia and sandstone formations. The whole sequence is more than 400 meters thick, and passes upwards into thin horizons of Palombini shale. The ophiolitic body of Cinghio del Corvo mainly consists of pillow basalt and pillow breccia capped by thin siliciclastic sediments. Thin horizons of ophiolitic sandstone and breccia are exposed to the south of Cinghio del Corvo, close to the Boccassuolo village, showing unclear spatial relationship with pillow basalts.

Several mining sites are known in the west-northwest part of Poggio-Bianco-Dragone, and north of Cinghio del Corvo. The deposits consist of reticulate quartz-calcite-sulfide veins varying from centimeters to more than one meter in thickness. The veins are emplaced in hydrothermally altered pillow basalt and basalt breccia. When hosted in pillow basalt the veins have cross cutting setting with preferential strikes close to $60^{\circ}$ and $120^{\circ}$ and subvertical dip (Figure 23a). The veins display a permeability-controlled concordant setting when emplaced into the breccia horizons (Figure 23b). The ophiolitic sandstone is not mineralized, although it shows diffuse infiltration by minute carbonate fissure filling, probably formed after the main hydrothermal event. The sulfide ore occurs as lowto high-grade dissemination of pyrite, chalcopyrite and sphalerite, with accessory galena, within the quartz-calcite gangue, accompanied by accessory chlorite, epidote, titanite and datolite. In general, pyrite has euhedral boundaries

\section{Corchia mine : "Cantiere Speranza"}
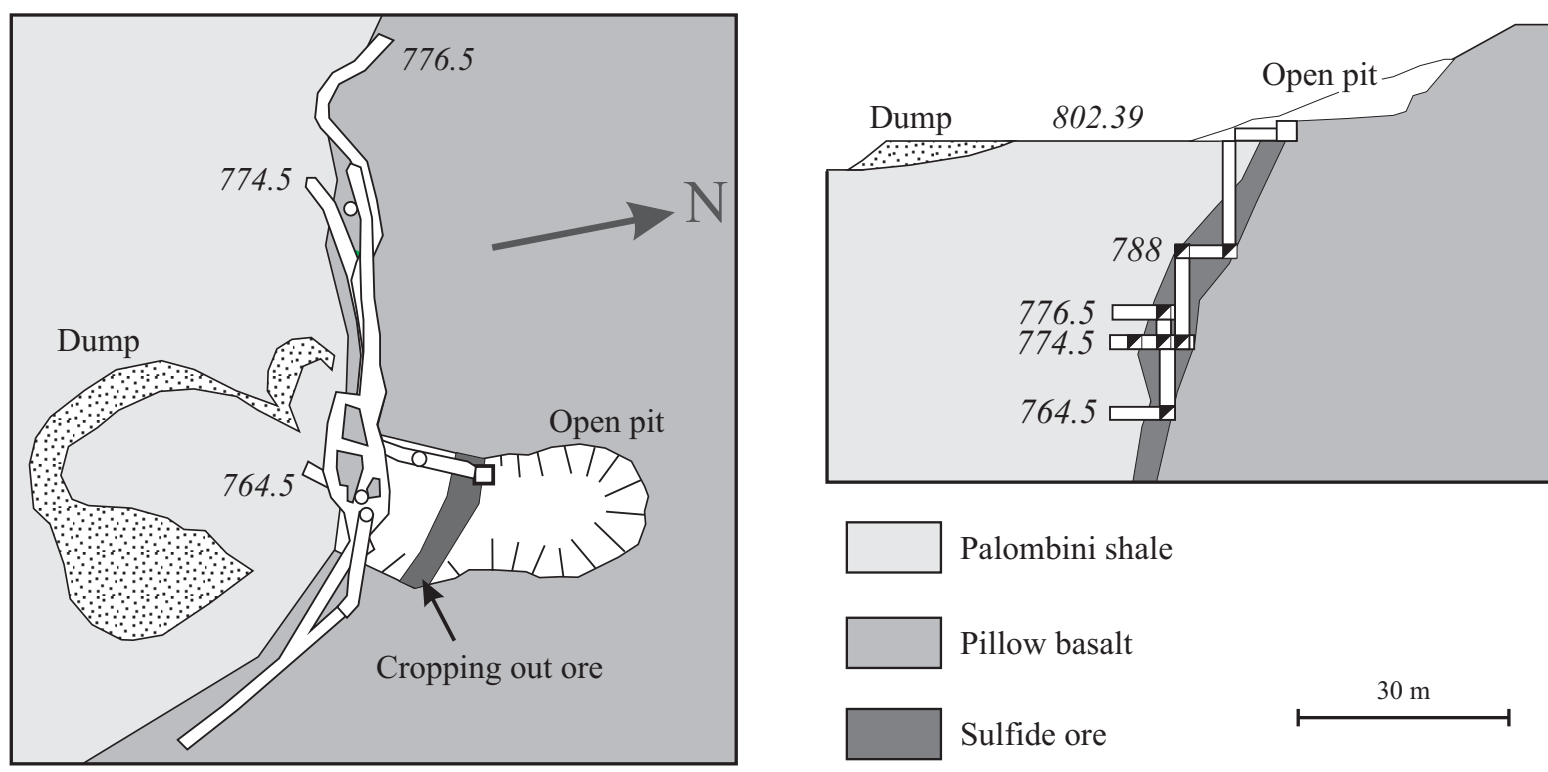

Figure 18. Plant and vertical section across the sulfide deposit at "Cantiere Speranza" of the Corchia mine. Redrawn after the "Società Industriale Mineraria del Rame", internal report of the state of works at May $1^{\text {th }} 1928$. Numbers in italic indicate altitudes above the sea level, in meters. 

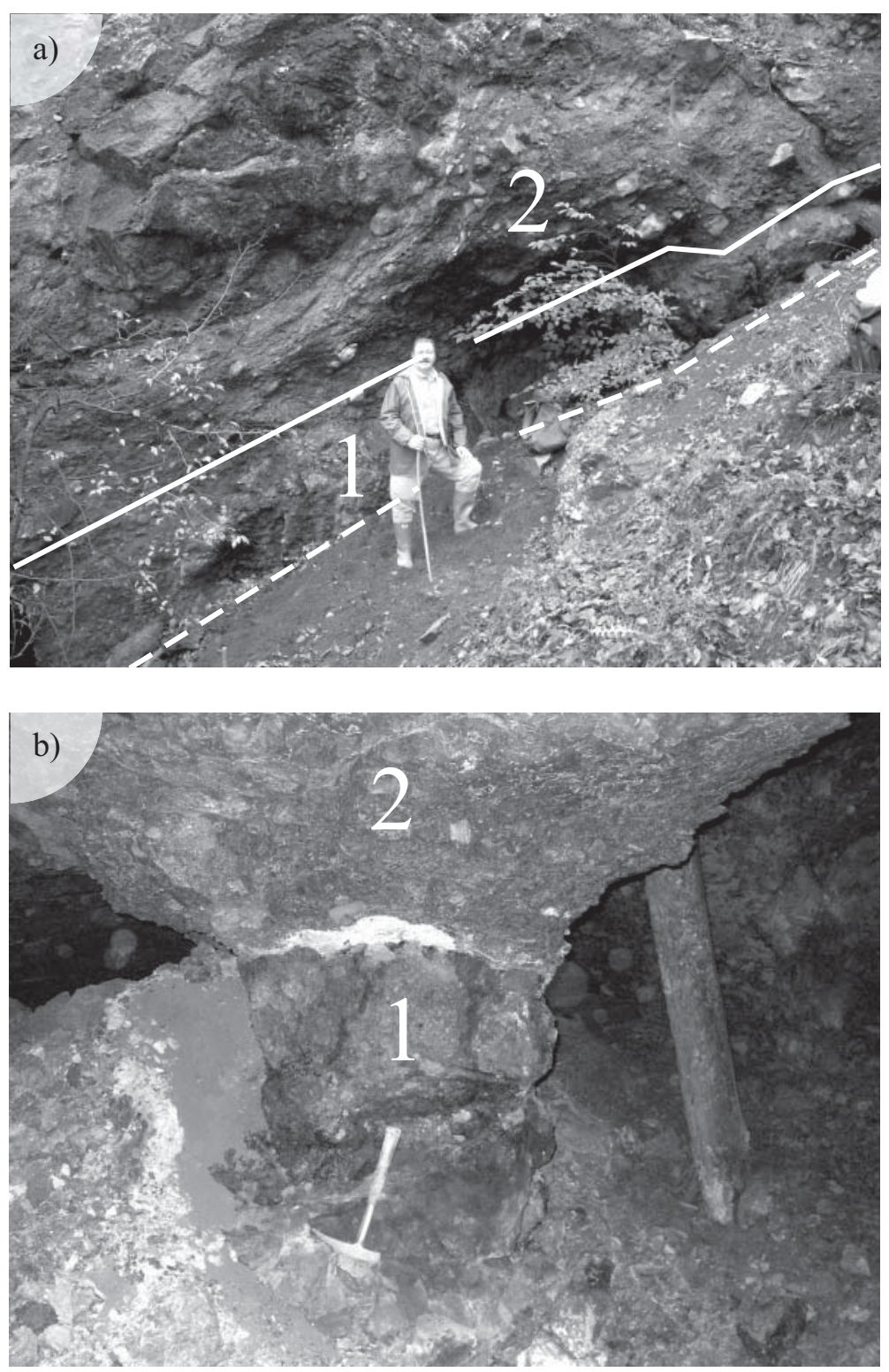

Figure 19. View of the Massive sulfide lens of the Corchia mine, a) external outcrop at the adit of "Cantiere Donnini"; b) underground view inside "Cantiere Donnini". 1) Massive sulfide at the top of pillow lava flow; 2) Palombini shale olistostroma. (photo Garuti, 2006).

and is replaced by chalcopyrite and sphalerite; however a late generation of pyrite is common, filling cracks and fissures in the other sulfides. Sphalerite typically contains blebs of chalcopyrite and pyrite concentrated in the core of the crystal, surrounded by homogeneous rims. A minute dissemination of pyrite is observed to extend into the country rock basalt for a few meters. In the sulfide ore biogenic features and $\mathrm{Au}-\mathrm{U}$ minerals are systematically absent.

Montecreto - Three small ophiolitic bodies are exposed on the right side of the Scoltenna creek, northwest of the Montecreto village. The ophiolites are immersed in a huge mass-flow of Palombini shale containing small blocks of basalt, gabbro and serpentinite (Figure 24). Although separated by the sedimentary mélange and partially rotated and overturned, in some case, the three bodies display lithological variations that allow reconstruction of the original stratigraphy. The largest body (il Bosco) consists of pillow basalt tectonically overlaying a coarse grained gabbro exposed to the north of the ophiolite and in underground mining works (Figure 25a). The smallest body (Cà Marsiglio) is composed of pillow basalt, ophiolitic breccia containing large fragments of pillows, ore veins and serpentinite (Figure 25b). Massive serpentinite is exposed in underground works along the east boundary of the ophiolitic body (Bertolani, 1953, 1999). The southernmost body (Cà Gabriele) is dominated by weakly deformed pillow basalt covered by a thin horizon (3-5 $\mathrm{m}$ ) of radiolarian chert cropping out along the southwest 


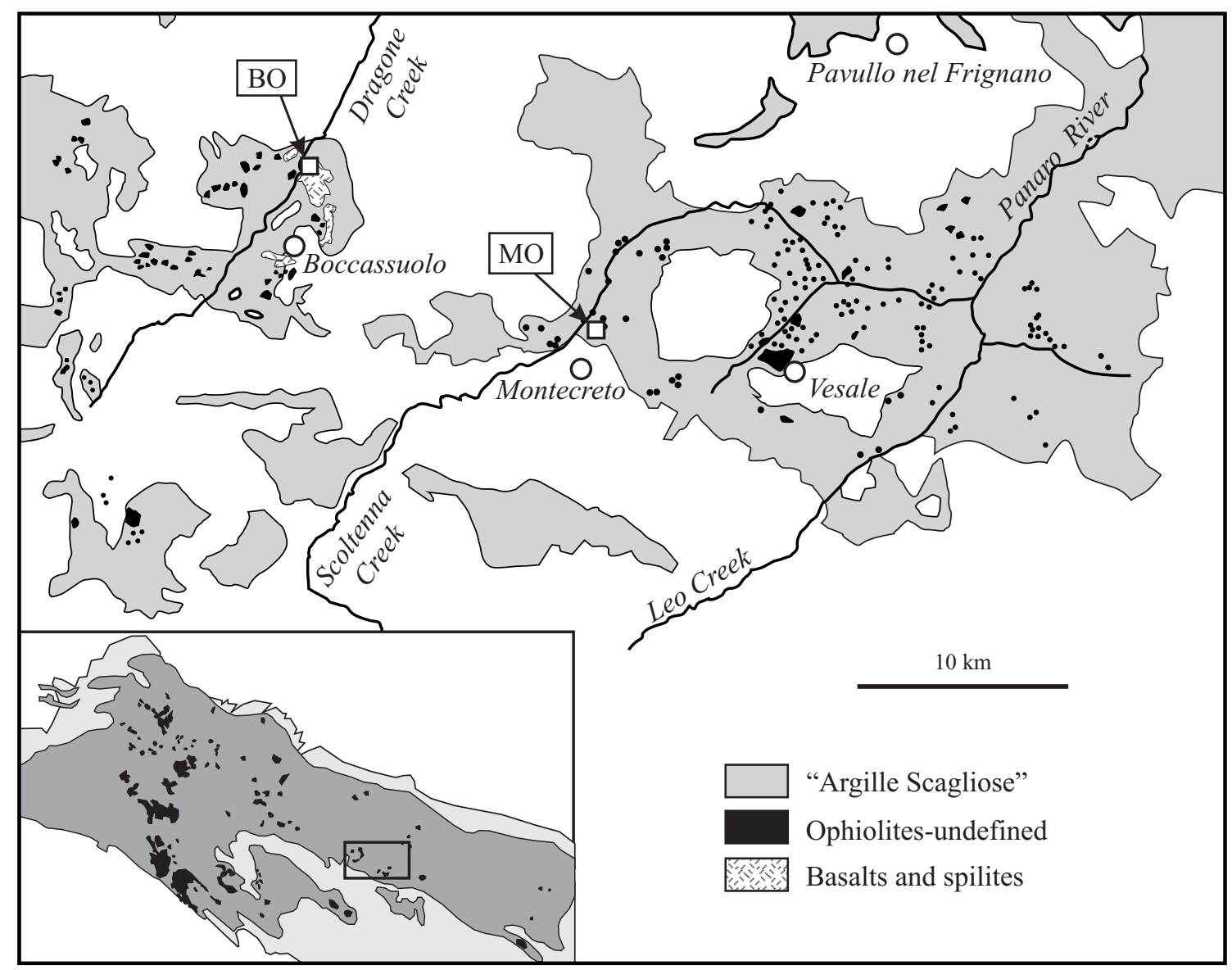

Figure 20. Geological sketch map of ophiolites in the External Ligurides of central Emilia Romagna (after Bertolani and Capedri 1966) and location of relevant sulfide deposits (after Zaccarini and Garuti in press). $\mathrm{BO}=$ Boccassuolo, $\mathrm{MO}=$ Montecreto. In the small framework, dark grey: Internal and External Ligurides undifferentiated, black: ophiolites. (see Table 3 for geographic coordinates of the deposits).

border of the ophiolite. Thus the Montecreto ophiolite as a whole represents a complete sequence, although fragmented, from the peridotite-gabbro basement, through basalt and basalt breccia, up to the pelagic sedimentary cover (chert). The sulfide ore is hosted in quartz-calcite veins emplaced in pillow basalt and ophiolitic breccia. The breccia is composed of centimeter to decimeter fragments of spilitic basalt, mineralized quartz veins and rare serpentinite cemented by quartz, carbonate and sulfide. Internal structure of the breccia suggests an origin by repeated cycles of hydro-fracturing and ore-gangue deposition. The sulfides display the typical assemblage pyrite-chalcopyrite-sphalerite disseminated in quartzcalcite-chlorite gangue, with accessory epiodote, titanite and serpentine. Abundant $\mathrm{Fe}-\mathrm{Ti}-\mathrm{Cr}$ oxides (ilmenite, rutile, hematite, magnetite, and chromite) occur in the breccia-hosted sulfide ore. The serpentine and chromite are texturally interpreted as detrital material derived by the erosion of ultramafic rocks (Garuti and Zaccarini, 2005; Zaccarini 2006). This conclusion is also supported by chemical and mineralogical data (Zaccarini and Garuti, in press) and suggests that the hydrothermal solution have cut across serpentinite before explosive intrusion into the basalt unit. Biogenic features and $\mathrm{Au}-\mathrm{Ag}-\mathrm{U}$ minerals are absent.

\section{Summary and conclusions}

The Cu-sulfide deposits associated with the northern Apennine ophiolites have mineralogy and composition similar to other ophiolite-hosted VMS deposits from allover the world. According to modern genetic models (Barrie and Hannington, 1999) they formed by precipitation of sulfide from metal-charged hydrothermal solutions, originated by convective circulation of heated and chemically modified seawater through the substrate of the Ligurian ocean (Ferrario and Garuti, 1980; Garuti and Zaccarini, 2005). Morphology and structure of the ore bodies indicate that precipitation of the sulfides occurred either within the rock substrate (stockwork-vein deposits) or at the seafloor (stratiform-stratabound deposits).

In contrast with most common ophiolite-hosted VMS deposits associated with basalts (Galley and Koski, 1999), 
Boccassuolo

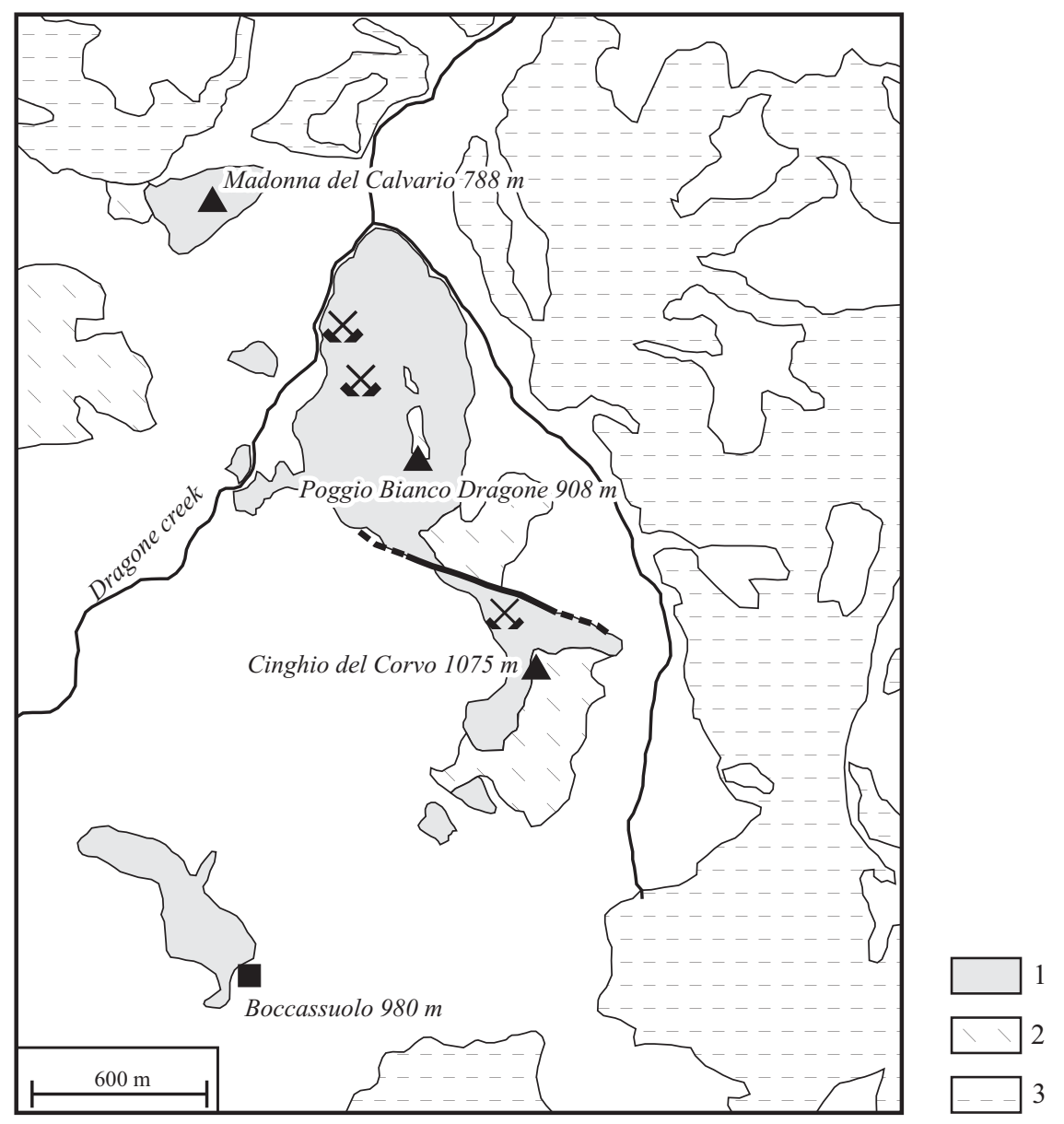

Figure 21. Geological sketch map of the Boccassuolo ophiolite hosting type-4c sulfide deposits. Modified after "Carta Geologica Regione Emilia Romagna". Symbols: 1 = undifferentiated pillow basalt and ophiolitic breccia, 2 = Palombini shale, 3 = Sedimentary mélange, "Argille Scagliose". 4 = flysch. Other symbols as in Figure 8.

the northern Apennine sulfide deposits display unusual association with both the volcanic cover and its ultramafic mantle basement. This feature raises the question of the relative timing of hydrothermal cells emplacement and deposition of the several sulfide ores now occurring in different stratigraphic position within the Ligurian ophiolites.

Stratiform sulfide ores within serpentinite breccia (Monte Bardeneto, Monte Bianco, Reppia I) were deposited on the serpentinite substrate, after erosion of the ultramafic basement and before the outflow of pillow basalt. Noteworthy, all the sulfide deposits of this type are invariably covered by lava flows, whereas no ore deposition has been observed where pelagic sediments rest directly over serpentinized mantle. Type-2 stratiform ores (Reppia II, Corchia) were deposited on eroded pillow-basalt flows, before deposition of cherts and other pelagic sediments. Both stratiform types underwent biogenic reworking, that was locally followed by mechanical erosion, debris flow and detrital resedimentation, indicating relatively longtime exposition to submarine conditions before burial.
The stratabound ore of Libiola (type 3) formed during the extrusion of pillow basalt probably in contact with seawater. The sulfide ore was readily covered by a lava flow and therefore did not undergo substantial reworking at the seafloor as testified by the absence of relevant biogenic and sedimentary features. Structural setting of stockwork deposits provides evidence that hydrothermal cells were emplaced across serpentinite (Vigonzano, Groppallo, Ferriere), gabbro (Casali) and basalt (Campegli, Monte Loreto, Boccassuolo, Montecreto). Spatial relationship between a stockwork-vein system and a stratiform deposit has been observed only in one case (Reppia II and III). In all cases examined in this work, stockwork-vein systems are cut at the top by erosion surfaces or tectonic shear planes, therefore genetic relationships with overlaying seafloor stratiform ores could not be established.

The establishment of convective cells through the Ligurian rock succession requires the availability of a seawater reservoir and a heat source emplaced at relatively shallow depth in the sub-seafloor lithosphere. In view of 


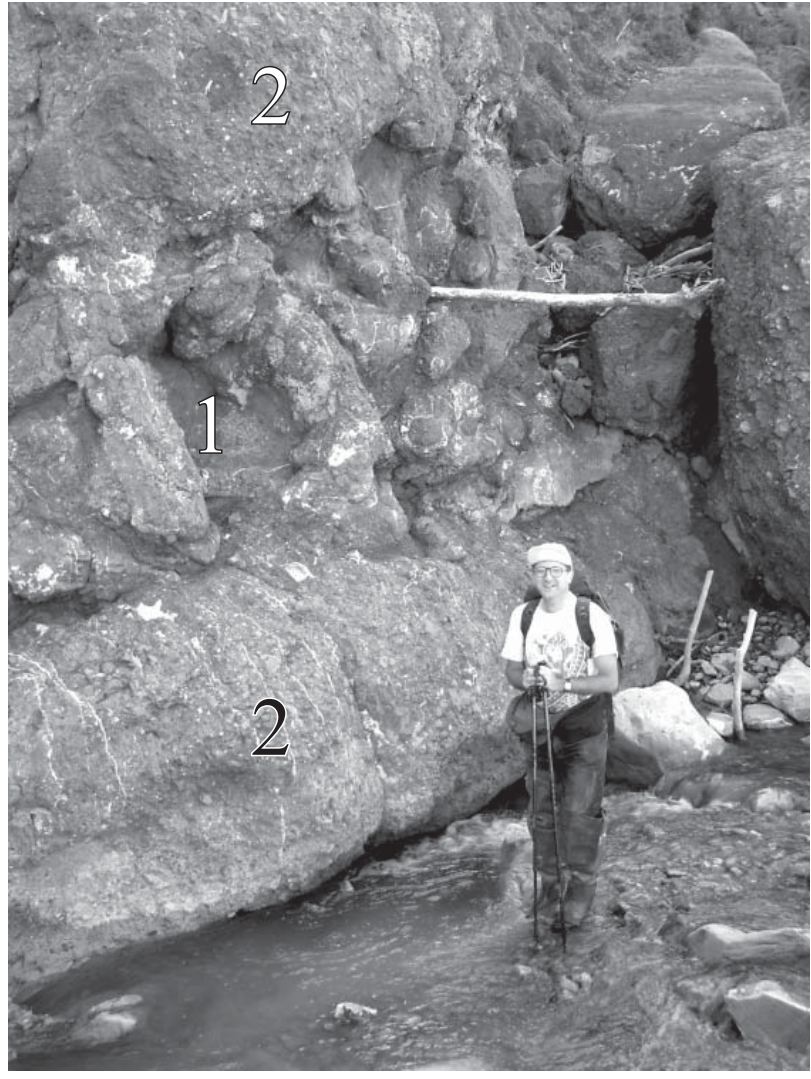

Figure 22. Boccassuolo ophiolite: outcrop showing the aletrnance of pillow lava flows (1) with ophiolitic breccia (2), Dragone river. (photo Garuti, 2006).

the geodynamic evolution of the Ligurian basin, these conditions may have been effective over a wide time span, from initial denudation of the serpentinte-gabbro basement at the ocean floor ( Lower Jurassic) to the decline of volcanic activity and onset of pelagic sedimentation (Lower Cretaceous). If this was the case, some of the stockwork deposits hosted in serpentinite and gabbro may be rather old, dating back to the early stages of ocean opening ( Lower Jurassic). On the other hand, the overall spatial relationships of stratiform and stratabound deposits of type 1,2 and 3 with the pillow lava unit suggests that deposition of sulfides on the seafloor occurred slightly before, during and after the outflow of MORB-like magma, in Middle- to Upper-Jurassic times, when the Ligurian basin reached its maximum opening.

In view of the above observations, we propose a model for the formation of the northern Apennine VMS deposits based on the assumption that the diffuse upraising of basaltic magma provided the heat source required for the establishment of a convective hydrothermal cell system throughout the Ligurian oceanic crust :

1) Initially, fluids interacted exclusively with the mantle basement, giving raise to deposition of sulfide in crosscutting stockwork-veins and seafloor-stratiform ore bodies
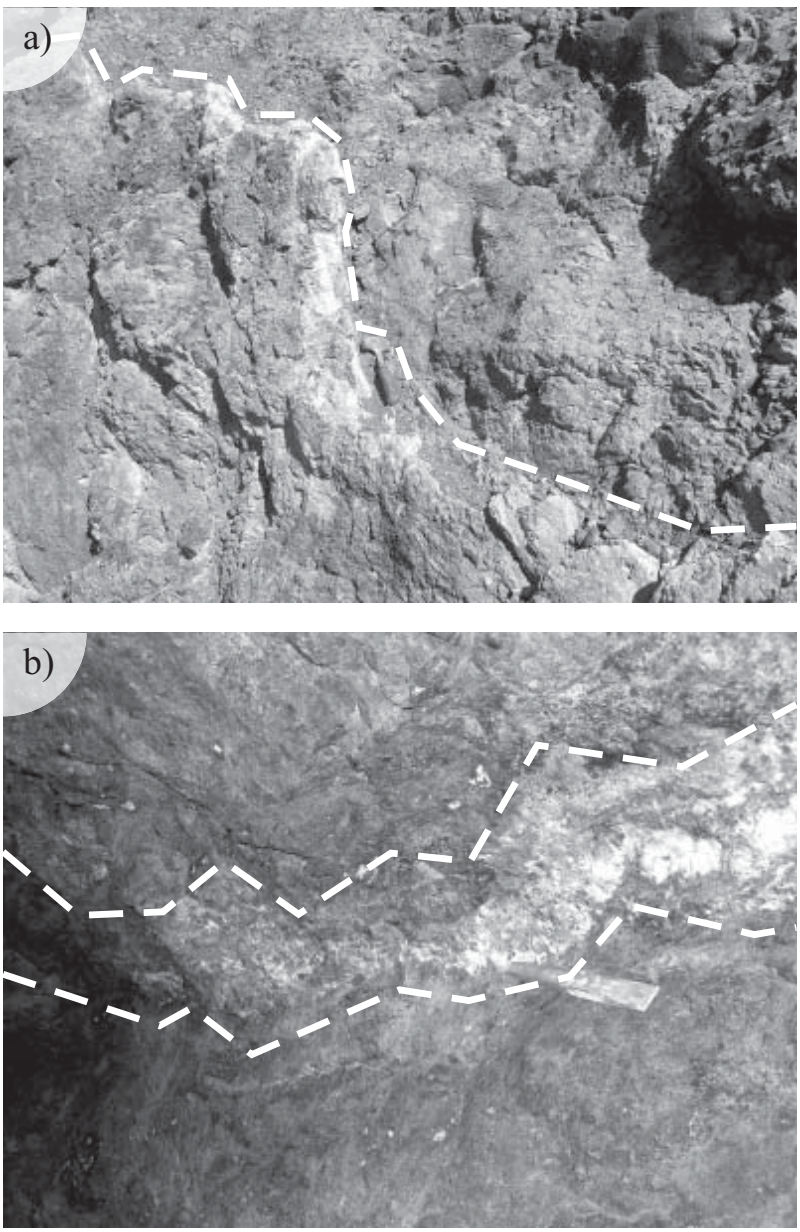

Figure 23. Boccassuolo ophiolite: a) outcrop showing the ore vein (quartz + calcite $+\mathrm{Cu}, \mathrm{Fe}, \mathrm{Zn}$ sulfide) vertically emplaced into pillow basalt at the locality "Filone Omar". b) underground view of an ore vein infiltrating the basalt breccia inside "Miniera dei due Livelli". (photo Garuti, 2006).

within serpentinized peridotite and serpentinite breccia, respectively. Sedimentary and biologic-mediated textures in stratiform ore were generated by submarine reworking of the ore, preceeding burial under pillow lava flows.

2) Hydrothermal activity continued during and after the eruption of pillow basalts, when fluids interacted mainly with mafic volcanics. Stockwork veins and conformable stratabound ore bodies within the basalt unit, as well as seafloor-stratiform deposits, at the top of the volcanic pile are formed in this stage. Biologic reworking and gravitational resedimentation processes affected the sulfide ore before burial under pelagic sediments.

3) The huge size of some stockwork deposits emplaced into thick bodies of pillow basalt and basalt breccias (i.e. Casali, Boccassuolo) indicate intensive circulation of fluids following extrusion of significant volumes of basaltic magma. Hydrothermal activity probably continued during early pelagic sedimentation, as it is supported by the occurrence of huge exhalative Mn deposits associated with 


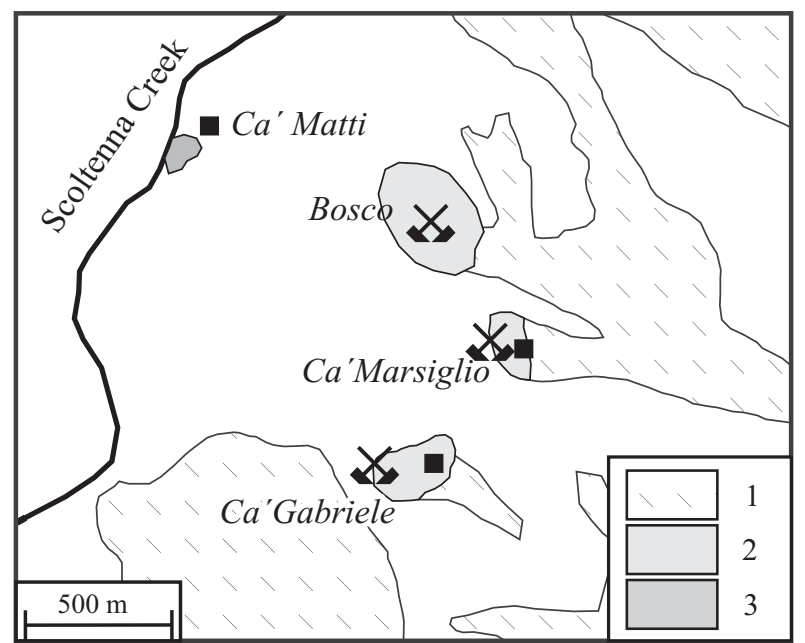

Montecreto

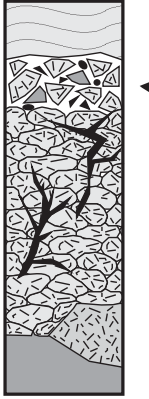

Radiolarian chert

Hydraulic breccia with

ultramafic fragments

Pillow basalt and veins

Gabbro and

Serpentinite

Figure 24. Geological sketch map (original mapping) and ideal stratigraphy of the Montecreto ophiolite hosting type-4c sulfide deposits. Symbols: $1=$ Palombini shale, 2 = pillow basalt, $3=$ gabbro.
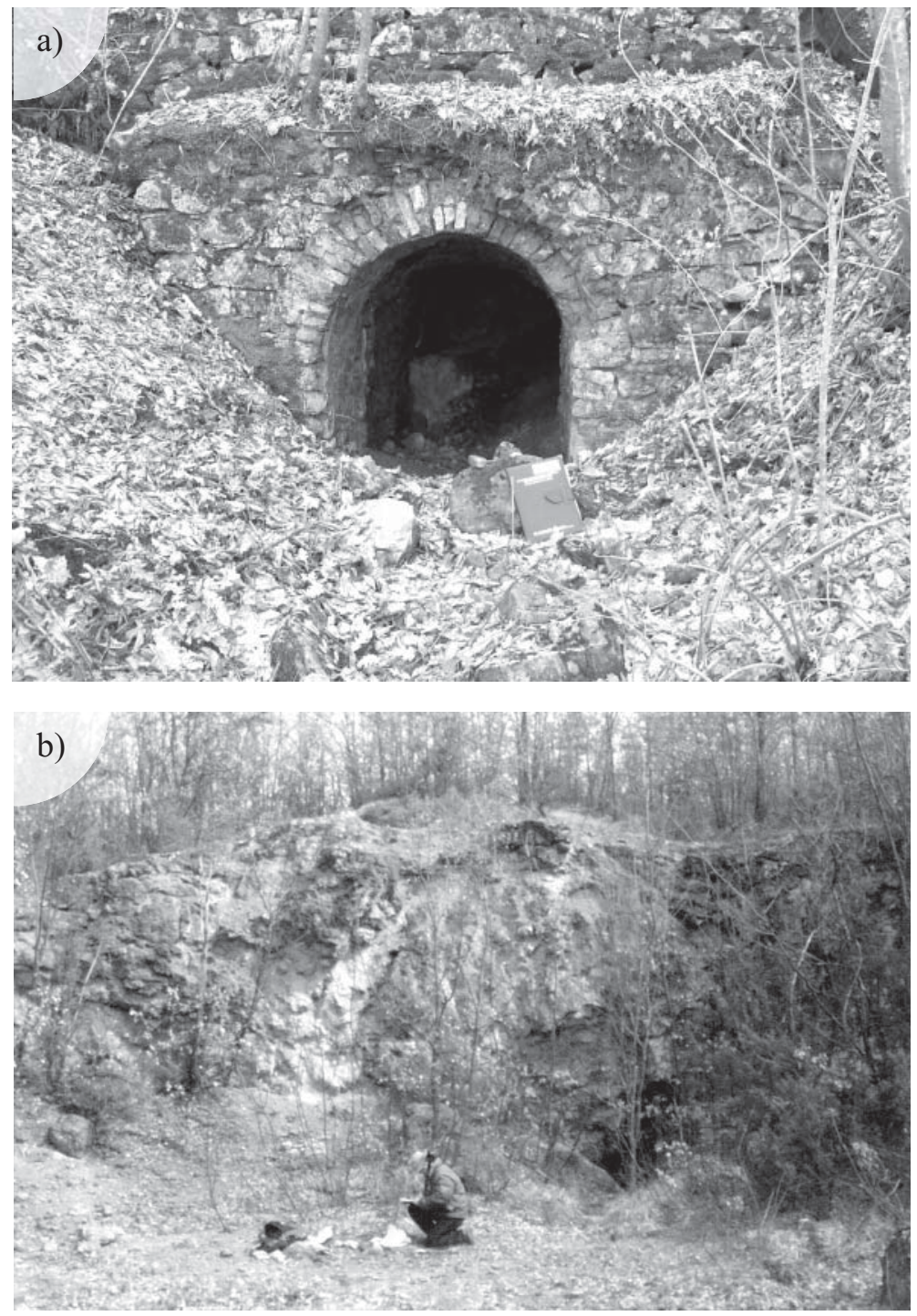

Figure 25. Montecreto ophiolite: a) adit of the "Bosco ceduo" mine inside pillow basalt. (photo Garuti, 2006). b) outcrop showing the horizon of mineralized breccia at "Geotritoni” gallery Cá Marsiglio. (photo Garuti, 2003). 
the Ligurian cherts (Bonatti et al., 1976; Cabella et al., 1998).

The northern Apennine sulfide ores represent a rare example of VMS deposits associated with basalt and serpentinized peridotite within the same ophiolite sequence. A similar unusual association has been recently reported from some VMS deposits in the southern Urals, where the host Paleozoic ophiolites appear to have evolved in a forearc geodynamic setting. (Nimis et al., 2007). The Ligurian ophiolites and their VMS deposits formed in an embryonic ocean in the western limb of the Mesozoic Tethys. Early geodynamic evolution of the basin occurred in a slowspreading center as a result of passive and asymmetric extension of the continental crust that caused exhumation of the upper mantle onto the seafloor, formation of numerous, ephemeral magma chambers at low depth in the oceanic lithosphere and outflow of small volumes of extrusive volcanic rocks (Piccardo et al., 2002). The resulting unconventional oceanic crust may have its modern analogues in the northern Red Sea embryonic ocean (Barret, 1982; Nicolas, 1984; Piccardo et al., 2002) or in the ocean-continent transition of the western Iberia margin discovered at site 897 of the Ocean Drilling Program (Gibson et al., 1996; Whitmarsh et al., 2001).

\section{Acknowledgements}

The authors wish to thank Renzo Baccarani, Valeriano Calderini, and Antonio Rossi for their precious help during exploration of the abandoned copper mines of the northern Apennines. Associated Editor Joaquin A. Proenza and the referees Pura Alfonso and Fernando Tornos are gratefully thanked for their editorial and scientific review of this paper.

\section{Bibliographic references}

Abbate, E., Bortolotti, V., Passerini, P., 1970, Development of the northern Apennine geosyncline. Olistostromes and olistoliths: Sedimentary Geology, 4, 521-557.

Abbate, E., Bortolotti, V., Principi, G., 1980, Apennine ophiolites: a peculiar oceanic crust in Rocci, G. (ed.), Tethyan ophiolites, Ofioliti Special Issue, 1, 59-96

Adorni, F., Guelfi, F., 1997, La miniera di Fe e Cu di Corchia, Berceto (Appennino Parmense): Rivista Mineralogica Italiana, 3, 217-250.

Barrett, T.J., 1982, Review of stratigraphic aspects of the ophiolitic rocks and pelagic sediments of the Vara complex, North Apennines, Italy: Ofioliti, 7/1, 3-46.

Barrett, T.J., Friedrichsen, H., 1989, Stable isotopic composition of atypical ophiolitic rocks from east Liguria, Italy: Chemical Geology, 80, 71-84.

Barrett, T.J., Spooner, E.T.C., 1977, Ophiolitic breccias associated with allochthonous oceanic crustal rocks in the East Ligurian Apennines, Italy: a comparison with observations from rifted oceanic ridges. Earth Planetary Science Letttters, 35, 79-91.

Barrie, C.T., Hannington, M.D. 1999, Classification of VolcanicAssociated Massive Sulfide deposits based on host-rock composition in Barrie, C.T., Hannington, M.D. (eds.), Volcanic-associated massive sulfide deposits: processes and examples in modern and ancient settings. Reviews in Economic Geology, 8, 1-11.

Bertolani, M., 1952, I giacimenti cupriferi nelle ofioliti di Sestri Levante: Periodico di Mineralogia, XXI 2/3, 149-170.

Bertolani, M., 1953, I giacimenti cupriferi dell' Appennino Modenese. Ricerche microscopiche a luce riflessa: Atti della Societá dei Naturalisti e Matematici di Modena, 82, 3-10.

Bertolani, M., 1959, Ricerche sulle rocce prasinitiche e anfibolitiche e sul giacimento metallifero di Vigonzano (Appennino piacentino): Atti della Societá dei Naturalisti e Matematici di Modena, 89/90, 3-31.

Bertolani, M., 1962, Linneite, calcopirrotina e strutture blenda-pirrotina nelle mineralizzazioni metallifere del giacimento di Corchia (Appennino Parmense): Periodico di Mineralogia, XXXI 2/3, 287-301.

Bertolani, M., 1999, Le antiche cave di pietra da taglio e le miniere storiche dell'Appennino Modenese in Provincia di Modena (ed.), Quaderni di documentazione ambientale, 12, pp.95.

Bertolani, M., Capedri, S., 1966, Le ofioliti delle province di Modena e Reggio Emilia: Atti della Societá dei Naturalisti e Matematici di Modena, 97, 3-52.

Biju-Duval, B., Dercourt, J., Le Pichon, X., 1977, From the Tethys Ocean to the Mediterranean Seas: a plate tectonic model of the evolution of the Western Alpine system in Biju-Duval, B., Montadert L. (eds.), Structural history of the Mediterranean basins. Editions Technip, Paris, 143-164.

Bonatti, E., Zerbi, M., Kay, R., Rydell, H., 1976, Metalliferous deposits from the Apennine ophiolites: Mesozoic equivalents of modern deposits from oceanic spreading centers: Bulletin of the Geological Society of America, 87, 83-94.

Brigo, L., Ferrario, A., 1974. Le mineralizzazioni nelle ofioliti della Liguria Orientale: Rendiconti della Societá Italiana di Mineralogia e Petrografia, 30, 305-316.

Cabella, R., Lucchetti, G., Marescotti, P. 1998, Mn-ores from Eastern Ligurian ophiolitic sequences ("Diaspri di monte Alpe" formaion, northern apennines, Italy): Trends in Mineralogy, 2, 1-17.

Capedri, S., Toscani, L., 2000, Subduction-related (?) ophiolitic metabasalts from Northern Apennines (Modena province, Italy): Chemie der Erde, 60, 111-128

Cortesogno, L., Giannelli, G., Piccardo, G.B., 1975, Petrogenesis and metamorphic evolution of the ophiolitic mafic rocks (Northern Apennine and Tuscany: Bollettino della Societá Geologica Italiana, 94, 291-327.

Cortesogno, L., Galbiati, B., Principi, G., Venturelli, G., 1978, Le brecce ofiolitiche della Liguria orientale: nuovi dati e discussione sui modelli paleogeografici: Ofioliti, 3, 99-160.

Cortesogno, L., Galbiati, B., Principi, G., 1987, Note alla "Carta geologica delle ofioliti del Bracco" e ricostruzione della paleogeografia Giurassico-Cretacica: Ofioliti, 12/2, 261-342.

Dal Piaz, G.V., 1971, Alcune considerazioni sulla genesi delle ofioliti piemontesi e dei giacimenti ad esse associati: Associazione Mineraria Subalpina, 3/4, 365-388.

Dal Piaz, G.V., 1974a, Le métamorphisme alpin de haute pression et basse temperature dans l'évolution structurale du bassin ophiolitique alpino-apenninique. - $1^{\mathrm{e}}$ partie: Bollettino della Societá Geologica Italiana, 93, 437-468.

Dal Piaz, G.V., 1974b, Le métamorphisme alpin de haute pression et basse temperature dans l'évolution structurale du bassin ophiolitique alpino-apenninique. - $2^{\mathrm{e}}$ partie: Schweitzer Mineralogische und Petrologische Mitteilungen, 57, 59-88.

Dal Piaz, G.V., 1995, Plate tectonics and mountain building: the Alps Historical review and personal comments in G., Ranelli, Ed., Proceedings of the VIII Summer School Earth and Planetary Sciences. Tipografia Senese (ed.), 171-251.

Dal Piaz, G.V., 1999, The Austroalpine-Piedmont nappe stack and the puzzle of Alpine Tethys: Memorie di Scienze Geologiche, 51, 155-176.

Decandia, F.A., Elter, G., 1972, La “zona ofiolitifera” del Bracco nel settore compreso fra Levanto e la Val Graveglia (Appennino Ligure): Memorie della Società Geologica Italiana, 11, 503-530.

Dewey, J.F., Pitman, W.C., Ryan, W.B.F., Bonnin, J., 1973, Plate 
tectonics and the evolution of the Alpine system: Bulletin of the Geological Society of America, 84, 3137-3180.

Elter, P., 1975. L'ensemble ligure: Bull. Soc. Géol. Fr., 17, 984-997.

Ferrario, A., 1973. I giacimenti cupriferi nelle pillow-lavas della Liguria Orientale: Rendiconti della Societá Italiana di Mineralogia e Petrografia, 29, 485-495.

Ferrario, A., 1977, Metallogeny of the Italian ophiolites in Jancovic, S. (ed.), Metallogeny and plate tectonics in the northeastern Mediterranean: IGCP - Correlation Project Nr.3, Faculty of Mining and Geology, Belgrade, 369-382.

Ferrario, A., Garuti, G., 1980, Copper deposits in the basal breccias and volcano-sedimentary sequences of the Eastern Ligurian ophiolites (Italy): Mineralium Deposita, 15, 291-303.

Galli, M., 1959, Sulla presenza di Argento nativo nella miniera di Libiola: Annali del Museo Civico di Storia Naturale, 71, 119-129.

Galli, M., Penco, A.M., 1996, Le miniere di rame e di manganese della Liguria orientale: Atti dell`Accademia Ligure di Scienze e Lettere, serie V, 53, 215-247.

Galley, A.G., Koski, R.A., 1999, Setting and characteristic of ophiolite-hosted volcanogenic massive sulfide deposits in Barrie, C.T., Hannington, M.D. (eds), Volcanic-associated massive sulfide deposits: processes and examples in modern and ancient settings: Reviews in Economic Geology, 8, 221-246.

Garuti, G., Zaccarini, F., 2005, Minerals of Au, Ag, and U in volcanic-rock-associated massive sulfide deposits of the Northern Apennine ophiolite, Italy: The Canadian Mineralogist, 43, 935-950.

Garuti, G., Alfonso, P., Zaccarini, F., Proenza, J.A., 2007, Sulphurisotope variations in seafloor and sub-seafloor, Cyprus-type VMS deposits of the NorthernApennine ophiolites (Italy): preliminary results in Andrew, C.J. et al. (eds), Digging deeper: Proceedings of the $9^{\text {th }}$ Biennal SGA Meeting, Dublin $20^{\text {th }}-23^{\text {rd }}$ August 2007. Vol. 2, 1041-1044.

Gibson, I.L., Beslier, M.O., Cornen, G., Milliken, K.L., Seifert, K.E., 1996, Major- and Trace-element seawater alteration profiles in serpentinite formed during the development of the Iberia Margin, site 897 in Whitmarsh, R.B., Sawyer, D.S., Klaus, A., Masson D.G. (eds.), Proceeding of the Ocean Drilling Program, Scientific results, 149, 519-527.

Goodfellow, W.D., Zierenberg, R.A., 1999, Genesis of massive sulfide deposits at sediment-covered spreading centers in Barrie, C.T., Hannington, M.D. (eds), Volcanic-associated massive sulfide deposits: processes and examples in modern and ancient settings: Reviews in Economic Geology, 8, 297-324.

Hutchinson, R.W., Fyfe, W.S., Kerrich, R., 1980, Deep fluid penetration and ore deposition: Minerals Sciences and Engineering, 12, 107-120.

Lemoine, M., Tricart, P., Boillot, G., 1987, Ultramafic and gabbroic ocean floor of the Ligurian Tethys (Alps, Corsica, Apennines): In search of a genetic model: Geology 15: 622-625

Leoni, L., Sartori, F., Tamponi, M., 1998, Compositional variation in Kmicas and chlorites coexisting in $\mathrm{Al}$-saturated metapelites under late diagenetic to low-grade metamorphic conditions (Internal Liguride Units, Northern Apennines, Italy): European Journal of Mineralogy, 10, 1321-1339.

Lombardo, B., Rubatto, D., Castelli, D., 2002, Ion microprobe U-Pb dating of Zircon from a Monviso metaplagiogranite: implication for the evolution of the Piedmont-Liguria Tethys in the Western Alps: Ofioliti, 27/2, 109-117.

Marroni, M., Molli, G., Montanini, A., Ottria, G., Pandolfi, L., Tribuzio, R., 2002, The External Ligurian units (Northern Apennine, Italy): from rifting to convergence of a fossil ocean-continent transition zone: Ofioliti, 27/2, 119-131.

Moretti, E., 1937, Autarchia Mineraria: L'Industria Mineraria d'Italia e d'Oltremare, anno XI/1, 12-16.

Nicolas, A., 1984, Lherzolites of the Western Alps: a structural review in Kornprobst, J. (ed.), Prooceedings of the $3^{\mathrm{d}}$ International Kimberlite Conference, Elsevier, Amsterdam, 333-345.
Nimis P, Zaykov VV, Omenetto P, Melekestseva I Yu, Tesalina SG, Orgeval J-J (2007) Peculiarities of some-ultramafic- and ultramafic-hosted massive sulfide deposits from the Main Uralian Fault Zone, southern Urals: Ore Geology Review, doi: 10.1016.05.010.

Pagani, G., Papani, G., Rio, D., Torelli, L., Zanzucchi, G., Zerbi, M., 1972, Osservazioni sulla giacitura delle ofioliti nelle alte valli del T. Ceno e del F. Taro: Memorie della Societá Geologica Italiana, $11,531-546$

Piccardo, G.B., Rampone, E., Romairone, A., 2002, Formation and composition of the oceanic lithosphere of the Ligurian Tethys: inferences from the Ligurian ophiolites: Ofioliti, 27/2, 145-161.

Pini, G.A., 1999, Tectonosomes and Olistostromes in the Argille Scagliose of the Northern Apennines, Italy: Geological Society of America, Special Paper 335, $70 \mathrm{p}$.

Pipino, G., 2003, Oro, miniere, storia - Miscellanea di giacimentologia e storia mineraria italiana: Monografia del Museo Storico dell'Oro Italiano, Lerma (Alessandria), $510 \mathrm{p}$.

Pognante, U., Piccardo, G.B., 1984, Petrogenesi delle ofioliti delle Alpi Occidentali: Memorie della Societá Geologica Italiana, 29, 79-92.

Principi, G., Cortesogno, L., Cellai, D., Gaggero, L., Garuti, G., Gazzotti, M., Passerini, P., Treves, B., 1992, Le ofioliti dell'Apennino settentrionale in Societa' Geologica Italiana, 76a Riunione Estiva, Firenze 24-25-26 settembre 1992, Guide alle Escursioni Post-congresso, 1-76.

Robertson, A.H.F. (2002). Overview of the genesis and emplacement of Mesozoic ophiolites in the Eastern Mediterranean Tethyan region: Lithos, 65, 1-67.

Sandrone, R., Leardi, G., Rossetti, P., Compagnoni, R., 1986, P-T conditions for the eclogite re-equilibration of the metaophiolites from Val d’Ala di Lanzo (Internal Piedmontese Zone, Western Alps): Journal of Metamorphic Geology, 4, 161-178.

Stuppini, M., 1998, Le miniere di Corchia nel parmense: Speleologia Emiliana, 9, 13-25.

Venturelli, G., Thorpe, R.S., Potts, P.J., 1981, Rare Earth and trace element characteristics of ophiolitic metabasalts from the AlpineApennine belt: Earth Planetary Science Letters, 53, 109-123.

Violi Guidetti, L., 1968: Le miniere di Val Dragone: Atti e Memorie di Deputazione di Storia Patria, 10, 369-378.

Whitmarsh, R.B., Minshull, T.A., Russel, S.M., Dean, S.M., Louden, K.E., Chain, D., 2001, The role of syn-rift magmatism in the rift-to-drift evolution of the west Iberia continental margin: geophysical observations in Wilson, R.C.L., Whitmarsh, R.B., Taylor, B., Froitzheim, N., (eds.), Non-volcanic rifting of continental margins: a comparison of evidence from land and sea. Special Publication of the Geological Society of London, 187, pp.107-124.

Zaccarini, F., 2006, Accessory minerals in volcanic massive sulfide deposits of the Northern-Apennine ophiolites (Italy): their petrogenetic significance: Resumen de Comunicaciones XXVI Reunion (SEM) / XX Reunion (SEa). Macla, 6, 505-508.

Zaccarini, F., Garuti, G., (in press), Mineralogy and composition of VMS deposits of northern Apennine ophiolites, Italy: evidence for the influence of country rock type on ore composition. Mineralogy and Petrology.

Zaccarini, F., Garuti, G., Rossi, A., Carrillo-Rosua, F.J., MoralesRuano, S., Fenoll Hach-Ali, P., 2003, Application of chlorite and Fluid-inclusion geothermometry to vein and stratiform $\mathrm{Fe}-\mathrm{Cu}-\mathrm{Zn}$ sulfide deposits of theNorthern Apennine Ophiolites (EmiliaRomagna and Liguria, Italy): Atti Ticinensi di Scienze della Terra, 9, 109-111.

Manuscript received: January 6, 2008

Corrected manuscript received: April 17, 2008

Manuscript accepted: May 8, 2008 